\title{
Seasonal variability in the inorganic ocean carbon cycle in the Northwest Pacific evaluated using a biogeochemical and carbon model coupled with an operational ocean model
}

\author{
Miho Ishizu $^{1}$ (D) Yasumasa Miyazawa $^{1} \cdot$ Tomohiko Tsunoda $^{2} \cdot$ Xinyu Guo $^{1,3}$
}

Received: 9 January 2020 / Accepted: 25 June 2020/Published online: 9 July 2020

(C) The Author(s) 2020

\begin{abstract}
Here, we investigate the seasonal variability in the dissolved inorganic carbon (DIC) cycle in the Northwest Pacific using a high-resolution biogeochemical and carbon model coupled with an operational ocean model. Results show that the contribution to DIC from air-sea $\mathrm{CO}_{2}$ exchange is generally offset by vertical mixing at the surface at all latitudes, with some seasonal variation. Biological processes in subarctic regions are evident at the surface, whereas in the subtropical region these processes take place within the euphotic layer and then DIC consumption deepens southward with latitude. Such latitudinal differences in biological processes lead to marked horizontal and vertical contrasts in the distribution of DIC, with modulation by horizontal and vertical advection-diffusion processes.
\end{abstract}

Keywords Biogeochemical model $\cdot$ Inorganic carbon cycle $\cdot$ NPZDC $\cdot$ Northwest Pacific $\cdot$ Ocean acidification $\cdot \mathrm{JCOPE} \cdot \mathrm{pH} \cdot$ Aragonite saturation

\section{Introduction}

The atmospheric partial pressure of $\mathrm{CO}_{2}\left(\mathrm{pCO}_{2}\right)$ has been increasing at a rate of $\sim 1.8 \mathrm{ppm}$ by volume (ppmv) per year in recent decades as a result of human activities such as fossil-fuel burning, deforestation, and cement production (Takahashi et al. 2009; IPCC 2013). In the preindustrial era, the ocean was generally a net source of $\mathrm{CO}_{2}$ emissions to the atmosphere because of the mineralization of land-derived organic matter in addition to that produced by in

Miho Ishizu

mishizu@jamstec.go.jp

1 Japan Agency for Marine-Earth Science and Technology, Yokohama-shi, Kanagawa, Japan

2 The Ocean Policy Research Institute of the Sasakawa Peace Foundation, Tokyo, Japan

3 Center for Marine Environmental Studies, Ehime University, Matsuyama, Japan 
situ production, and $\mathrm{CaCO}_{3}$ precipitation (Mackenzie et al. 2004). Rising atmospheric $\mathrm{CO}_{2}$ concentrations caused by fossil-fuel combustion and land-use changes (Mackenzie et al. 2004; Bauer et al. 2013; IPCC 2013; IGBP, IOC, SCOR 2013) reversed the direction of the air-sea $\mathrm{CO}_{2}$ flux, leading the global ocean to become a net sink of anthropogenic $\mathrm{CO}_{2}$. The present thickness of the upper thermocline, where large amounts of anthropogenic $\mathrm{CO}_{2}$ emissions are stored, is estimated to be of the order of a few hundred meters (Mackenzie et al. 2004). The oceanic coastal zone changed from being a source to a sink during the industrial era (Mackenzie et al. 2004; Bauer et al. 2013). Several estimates of $\mathrm{CO}_{2}$ sinks and sources in ocean provinces (Cai et al. 2006) and/or spatially explicit typology (Laurelle et al. 2010) showed that marginal seas in the tropics are sources of $\mathrm{CO}_{2}$, whereas those in temperate regions and at high latitudes act as sinks (Cai et al. 2006; Laurelle et al. 2010).

Data-based estimates of variability and trends in ocean $\mathrm{CO}_{2}$ uptake are limited by the short record of observations. Although high-quality measurements of $\mathrm{CO}_{2}$ in surface waters and air commenced in the early 1960s, the amount of available information is still limited (Wanninkhof et al. 2013). The principal observational approaches for estimating sea-air fluxes of $\mathrm{CO}_{2}$ are to measure $\Delta \mathrm{pCO}_{2}$ from ships (Takahashi et al. 2009; Nakaoka et al. 2013) and moorings (Sutton et al. 2017), and apply a parameterization using a function of wind speed (Wanninkhof et al. 2013). Other approaches rely on simulations made by ocean biochemistry general circulation models (OBGCMs) with parameterization of biogeochemical processes and total dissolved inorganic carbon (DIC) measurements in the ocean interior, and/or atmospheric data. However, gaps remain in the understanding of ocean $\mathrm{CO}_{2}$ uptake, especially the spatiotemporal variability of the seasonal inorganic/organic carbon cycle, because $\mathrm{CO}_{2}$ concentrations and other related oceanic variables are difficult to observe simultaneously, frequently, and widely. The seasonal variability in $\mathrm{pCO}_{2}$ shows differences at a local scale (Takahashi et al. 2009; Sutton et al. 2017). Model estimates of temporal trend detection (Keller et al. 2014; Lovenduski et al. 2015) show the influence of both decadal/interannual and seasonal variabilities and suggest that the time of emergence of a trend signal is basically around 10 years in the surface but the tropical area needs more time.

The detailed processes that generate variation in the DIC of the ocean interior are still uncertain. Several studies have proposed possible mechanisms for the oceanic annual carbon cycle (Palmer and Totterdell 2001; Takahashi et al. 2002; Xiu and Chai 2013). Palmer and Totterdell (2001) discussed physical and biological mechanisms that contribute to the global annual mean carbon cycle using an ecosystem model without considering the contribution of air-sea $\mathrm{CO}_{2}$ exchange. They reported that the effects of vertical mixing were largely offset by biological processes in the latitudinal range of $25-60^{\circ} \mathrm{N}$ over ocean surfaces and that the effects of advection were mostly offset by biological processes at latitudes of $<20^{\circ} \mathrm{N}$. Takahashi et al. (2009) focused on the relative importance of temperature and biological effects to the global seasonal cycle of air-sea $\mathrm{CO}_{2}$ exchange by evaluating monthly climatological maps of air-sea $\mathrm{CO}_{2}$ flux and $\mathrm{pCO}_{2}$. Xiu and Chai (2013) investigated the seasonal and decadal variability of the upper-ocean carbon cycle in the North Pacific using a physical-biogeochemical model. Their results showed that the seasonal variability in $\mathrm{pCO}_{2}$ and $\mathrm{CO}_{2}$ flux in the North Pacific followed the change in sea surface temperature closely, with high and low values in summer and winter, respectively, and that surface $\mathrm{pCO}_{2}$ variations at the modeled sites correspond to well-known observational monitoring points controlled primarily by anthropogenic $\mathrm{CO}_{2}$ and modulated by decadal variations.

The Japan Coastal Ocean Predictability Experiment (JCOPE; http://www.jamstec.go. jp/jcope/) is an operational eddy-resolving physical ocean model for the Northwest Pacific, the Japan Sea, the Okhotsk Sea, and the East China Sea (Miyazawa et al. 2009, 2014). Ishizu et al. (2019) recently developed a biogeochemical and carbon model coupled with the JCOPE 
(JCOPE_EC). This model generally reproduces the observed seasonal variability of chlorophyll-a (Chl-a), dissolved inorganic nitrogen (DIN), phosphorus (DIP), and inorganic carbon (DIC), and total alkalinity (ALK), but includes monthly climatological damping for DIN, DIP, DIC, and ALK (Ishizu et al. 2019). The damping forcibly constrains the calculated biological parameters (DIN, DIP, DIC, and ALK) around the monthly climatological values with a timescale of 30 days (Ishizu et al. 2019), meaning that those authors were unable to discuss the mechanism of the inorganic carbon cycle. In this study, we therefore performed a simulation using JCOPE_EC without any climatological damping and examined the physical and biological mechanisms represented by the model dynamics, focusing on the critical roles of horizontal and vertical advection-diffusion processes in generating seasonal variation in DIC.

We present the results from JCOPE_EC (without climatological damping) and discuss the mechanisms responsible for the simulated seasonal inorganic carbon cycle for the Northwest Pacific. Details of the model configuration are given in Section 2, model accuracy is described in Section 3, the processes involved in the inorganic carbon cycle in the model are discussed in Section 4, and the conclusions of the study are provided in Section 5.

\section{Model and data}

\subsection{Model configuration}

The JCOPE_EC (Ishizu et al. 2019) is an off-line tracer model driven by physical processes simulated by an operational eddy-resolving ocean general circulation model (JCOPE2M; Miyazawa et al. 2017) based on the Princeton Ocean Model with a generalized sigma coordinate (Mellor 2001). The model is a three-dimensional high-resolution regional model covering the Northwest Pacific $\left(108-180^{\circ} \mathrm{E}, 10.5-62^{\circ} \mathrm{N}\right)$ with a horizontal resolution of $1 / 12^{\circ}$ $(4.4-9.1 \mathrm{~km})$ and 46 vertical active levels. The model structure is the same as that described by Ishizu et al. (2019), but our model differs in that the governing equations for DIN, DIP, DIC, and ALK (equations 4, 5, 17, and 18 of Ishizu et al. 2019) remove climatological damping.

We determined the biogeochemical model parameters using multi-optimized operations (Ishizu et al. 2019) separately for subarctic and subtropical regions (Table 1). These biogeochemical parameters are the maximum growth rate from photosynthesis $\left(V_{\max }\right)$, the phytoplankton mortality rate at $0{ }^{\circ} \mathrm{C}\left(M_{\mathrm{P}}\right)$, the phytoplankton respiration rate $(R)$, the maximum grazing rate of zooplankton $\left(G_{\mathrm{z}}\right)$, the zooplankton mortality rate $(M)_{\mathrm{z}}$, the decomposition rate $\left(V_{\mathrm{PN}}\right)$, and the optimum light intensity for phytoplankton $\left(I_{\mathrm{opt}}\right)$. In addition to the parameters described in Ishizu et al. (2019), we introduced latitudinal changes in $V_{\max }, M_{\mathrm{P}}, R, M_{\mathrm{z}}, V_{\mathrm{PN}}$, and $I_{\text {opt }}$ according to the results of several sensitivity experiments as follows:

$$
\begin{aligned}
& V_{\max }=0.5 V_{\max }^{0}\left(\tan h\left(\left(\text { Lat } \text { Lat }_{\text {bnd.vmax }}\right) / \text { Lat }_{\text {slp }}\right)+1\right)+V_{\max }^{1} \\
& M_{\mathrm{P}}=0.5 M_{\mathrm{P}}^{0}\left(\tan h\left(\left(\mathrm{Lat}^{-\mathrm{Lat}_{\text {bnd }}}\right) / \mathrm{Lat}_{\mathrm{slp}}\right)+1\right)+M_{\mathrm{P}}^{1} \\
& R=0.5 R^{0}\left(\tan h\left(\left(\text { Lat }^{- \text {Lat }_{\text {bnd }}}\right) / \text { Lat }_{\text {slp }}\right)+1\right)+R^{1}
\end{aligned}
$$




$$
\begin{aligned}
& M_{\mathrm{Z}}=0.5 M_{\mathrm{Z}}^{0}\left(\tan h\left(\left(\mathrm{Lat}^{-\mathrm{Lat}_{\text {bnd }}}\right) / \mathrm{Lat}_{\mathrm{slp}}\right)+1\right)+M_{\mathrm{Z}}^{1} \\
& V_{\mathrm{PN}}=0.5 V_{\mathrm{PN}}^{0}\left(\tan h\left(-\left(\mathrm{Lat}_{-} \mathrm{Lat}_{\mathrm{bnd}}\right) / \mathrm{Lat}_{\mathrm{slp}}\right)+1\right)+V_{\mathrm{PN}}^{1} \\
& I_{\mathrm{opt}}=0.5 I_{\mathrm{opt}}^{0}\left(\tan h\left(-\left(\mathrm{Lat}^{-\mathrm{Lat}_{\mathrm{bnd}}}\right) / \mathrm{Lat}_{\mathrm{slp}}\right)+1\right)+I_{\mathrm{opt}}^{1}
\end{aligned}
$$

where $V_{\max }, M_{\mathrm{P}}, R, M_{\mathrm{z}}, V_{\mathrm{PN}}$, and $I_{\mathrm{opt}}$ change latitudinally from 0.28 to 0.97 day $^{-1}, 0.054$ to $0.155\left(\mathrm{mmol} \mathrm{Nm}^{-1}\right) \mathrm{m}^{-3}$ day $^{-1}, 0.0011$ to 0.00256 day $^{-1}, 0.044$ to $0.12\left({ }^{\circ} \mathrm{C}\right)^{-1}, 0.0954$ to 0.47 day $^{-1}$, and from 20 to $100 \mathrm{~W} \mathrm{~m}{ }^{-2}$, respectively; $V_{\max }{ }^{0}, R^{0}, M_{\mathrm{P}}^{0}, M_{\mathrm{z}}^{0}, V_{\mathrm{PN}^{0}}{ }^{0} I_{\mathrm{opt}}{ }^{0}, V_{\max }{ }^{1}, R^{1}$, $M_{\mathrm{P}}{ }^{1}, M_{\mathrm{z}}{ }^{1}, V_{\mathrm{PN}}{ }^{1}$, and $I_{\mathrm{opt}}{ }^{1}$ are the tunable parameters (Table 1); Lat ${ }_{\text {bnd.vmax }}$, Lat ${ }_{\text {bnd }}$, and $\mathrm{Lat}_{\text {slp }}$ are the coefficients representing the values at latitudinal boundaries and the latitudinal slopes for these parameters, respectively (Table 1 and Eqs. 1, 3, 4, 5, and 6).

The first version of JCOPE_EC had a model bias resulting in a large decrease in ALK in summer due to anomalously high $\mathrm{CaCO}_{3}$ production with a large increase in Chl-a during summer in subarctic regions (Ishizu et al. 2019). To suppress this large decrease in ALK in this model, we set the $\mathrm{CaCO}_{3}$ to non-photosynthetic $\mathrm{POC}$ production ratio to a much smaller value $(0.00035)$ in the version of the model used here (Table 1). This improvement allows the model to well represent the seasonal variability of ALK in our target region (Section 3).

The model was driven by forcing from daily oceanic (JCOPE2M) and six-hourly atmospheric (NCEP/NCAR) reanalysis data for a 1-year period (2015). The initial concentrations of phytoplankton were set to 0.1 and $0.0 \mathrm{mmol} \mathrm{N} \mathrm{m}^{-3}$ for depths above and below $150 \mathrm{~m}$, respectively. The initial zooplankton concentrations were set to $10 \%$ of the phytoplankton concentration. The initial detritus concentration was set to $0.0 \mathrm{mmol} \mathrm{N} \mathrm{m}^{-3}$. The variables DIN, DIP, and DIC were initialized using the climatology for January, and ALK was initialized using the annual climatology (Ishizu et al. 2019).

\subsection{Model validation}

To validate phytoplankton concentrations in the model, MODIS-Aqua Ocean Color Data for Chl-a from 2015 were used, as downloaded from the website of the Physical Oceanography Distributed Active Archive Center (PODAAC). To validate the model results for DIN, DIP, and DIC, we used monthly climatological DIN, DIP, and DIC data (World Ocean Atlas 2013 (WOA13); Yasunaka et al. 2013) and Japan Meteorological Agency (JMA) observational data for 2015, as in Ishizu et al. (2019). There are no applicable monthly climatological datasets for ALK in our target region (Goyet et al. 2000; Key et al. 2004; Takatani et al. 2014, Takahashi et al. 2014). We therefore used ALK observational data obtained by JMA in 2015 for comparison with model results (Section 3).

\section{Results}

\subsection{Accuracy of modeled Chl-a, DIN, DIC, and ALK}

Model results presented here are slightly less accurate than those of the model with the climatological conditions described by Ishizu et al. (2019), except for ALK. However, the 
Table 1 Biogeochemical parameters in JCOPE_EC without the climatological condition. An asterisk in the value column signifies that latitudinal differences are the biogeochemical parameters adopted latitudinal differences from Eqs. 1-6

\begin{tabular}{|c|c|c|c|c|}
\hline Symbol & Definition & Value & Units & $\begin{array}{l}\text { Referenced } \\
\text { values } \\
\text { Ishizu et al. } \\
2019\end{array}$ \\
\hline
\end{tabular}

\begin{tabular}{|c|c|c|c|c|}
\hline \multicolumn{5}{|c|}{ Ecosystem model } \\
\hline \multicolumn{5}{|c|}{ For phytoplankton } \\
\hline$V_{\max }$ & Growth rate for phytoplankton & $* 0.28-0.97$ & day $^{-1}$ & 0.0492 \\
\hline$V_{\text {opt }}{ }^{\max }$ & & 0.690 & & \\
\hline$V_{\text {opt }} 1$ & & 0.625 & & \\
\hline lat ${ }_{\text {bnd.vmax }}$ & $\begin{array}{l}\text { Boundary for latitudinal } \\
\text { differences in growth rate for } \\
\text { phytoplankton }\end{array}$ & 40.0 & & \\
\hline$A$ & $\begin{array}{l}\text { Affinity coefficient of basic } \\
\text { cellular physiology }\end{array}$ & 6.75 & mmol $\mathrm{N} \mathrm{m}^{-1}$ day $^{-1}$ & \\
\hline$M_{P}$ & $\begin{array}{l}\text { Phytoplankton mortality rate at } \\
0{ }^{\circ} \mathrm{C}\end{array}$ & $* 0.054-0.155$ & $\left(\mathrm{mmol} \mathrm{N} \mathrm{m}{ }^{-1}\right) \mathrm{m}^{-3}$ day $^{-1}$ & 0.04 \\
\hline$P_{\min }$ & $\begin{array}{l}\text { Threshold of phytoplankton } \\
\text { mortality }\end{array}$ & 0.0587 & $\left(\mathrm{mmol} \mathrm{N} \mathrm{m}{ }^{-1}\right) \mathrm{m}^{-3}$ & \\
\hline$R$ & $\begin{array}{l}\text { Phytoplankton respiration rate at } \\
0^{\circ} \mathrm{C}\end{array}$ & $* 0.0011-0.00256$ & day $^{-1}$ & 0.0317 \\
\hline$R_{\mathrm{opt}}{ }^{0}$ & & 0.00147 & & \\
\hline$R_{\mathrm{opt}}{ }^{1}$ & & 0.00185 & & \\
\hline$C_{\mathrm{T}}^{\mathrm{P}}$ & $\begin{array}{l}\text { Temperature coefficient for } \\
\text { photosynthesis }\end{array}$ & 0.0392 & ${ }^{\circ} \mathrm{C}^{-1}$ & \\
\hline$C^{\mathrm{RP}_{\mathrm{T}}}$ & $\begin{array}{l}\text { Temperature coefficient for } \\
\text { phytoplankton respiration }\end{array}$ & 0.0519 & ${ }^{\circ} \mathrm{C}^{-1}$ & \\
\hline$C^{\mathrm{MP}}{ }_{\mathrm{T}}$ & $\begin{array}{l}\text { Temperature coefficient for } \\
\text { phytoplankton mortality }\end{array}$ & 0.0693 & ${ }^{\circ} \mathrm{C}^{-1}$ & \\
\hline$I_{\mathrm{opt}}$ & $\begin{array}{l}\text { Optimum light intensity for } \\
\text { phytoplankton }\end{array}$ & $* 20-120$ & $\mathrm{~W} \mathrm{~m} \mathrm{~m}^{-2}$ & $* 20-120$ \\
\hline$I_{\mathrm{opt}}{ }^{0}$ & & 100.0 & & \\
\hline lat $t_{\text {bnd }}$ & $\begin{array}{l}\text { Boundary for latitudinal } \\
\text { differences }\end{array}$ & 45.0 & & \\
\hline $\operatorname{lat}_{\text {slp }}$ & Slope for latitudinal differences & 4.0 & & \\
\hline$c_{\mathrm{dom}}$ & $\begin{array}{l}\text { Light dissipation coefficient of sea } \\
\text { water }\end{array}$ & 0.015 & $\mathrm{~m}^{-1}$ & $* 0.015-0.045$ \\
\hline Lat $_{\text {slp_dom }}$ & $\begin{array}{l}\text { Slope for latitudinal differences } \\
\text { for }{ }^{c} \text { dom }\end{array}$ & 1.5 & & \\
\hline \multicolumn{5}{|c|}{ For zooplankton } \\
\hline$G_{\mathrm{Z}}$ & $\begin{array}{l}\text { Maximum grazing rate of } \\
\text { zooplankton at } 0^{\circ} \mathrm{C}\end{array}$ & 0.423 & day $^{-1}$ & \\
\hline$\lambda$ & Ivlev constant & 1.4 & $\left.(\mathrm{mmol} \mathrm{N} \mathrm{m})^{-3}\right)^{-1}$ & \\
\hline$M_{\mathrm{Z}}$ & Zooplankton mortality rate at $0{ }^{\circ} \mathrm{C}$ & $* 0.044-0.12$ & ${ }^{\circ} \mathrm{C}^{-1}$ & 0.05 \\
\hline$M_{\mathrm{Z}}^{0}$ & & 0.0760 & & \\
\hline$M_{\mathrm{Z}}^{1}$ & & 0.0825 & & \\
\hline$\beta_{\mathrm{z}}$ & Growth efficiency of zooplankton & 0.3 & & \\
\hline$\alpha_{\mathrm{z}}$ & $\begin{array}{l}\text { Assimilation efficiency of } \\
\text { zooplankton }\end{array}$ & 0.7 & & \\
\hline$P^{*}$ & $\begin{array}{l}\text { Zooplankton threshold value for } \\
\text { grazing on phytoplankton }\end{array}$ & 0.0430 & $\left(\mathrm{mmol} \mathrm{N} \mathrm{m} \mathrm{m}^{-1}\right) \mathrm{m}^{-3}$ & \\
\hline$C^{\mathrm{GZ}}{ }_{\mathrm{T}}$ & $\begin{array}{l}\text { Temperature coefficient for } \\
\text { zooplankton grazing }\end{array}$ & 0.0390 & ${ }^{\circ} \mathrm{C}^{-1}$ & \\
\hline$C^{\mathrm{MP}}{ }_{\mathrm{T}}$ & $\begin{array}{l}\text { Temperature coefficient for } \\
\text { zooplankton mortality }\end{array}$ & 0.0693 & ${ }^{\circ} \mathrm{C}^{-1}$ & \\
\hline
\end{tabular}


Table 1 (continued)

\begin{tabular}{|c|c|c|c|c|}
\hline Symbol & Definition & Value & Units & $\begin{array}{l}\text { Referenced } \\
\text { values } \\
\text { Ishizu et al. } \\
\quad 2019\end{array}$ \\
\hline \multicolumn{5}{|l|}{ For diatoms } \\
\hline$W_{\mathrm{D}}$ & Singing velocity of detritus & 6.7 & $m$ day $^{-1}$ & \\
\hline$V_{\mathrm{PN}}$ & $\begin{array}{l}\text { Decomposition rate at } 0{ }^{\circ} \mathrm{C} \\
(\text { DET } \rightarrow \text { DIN) }\end{array}$ & $* 0.0954-0.28$ & day $^{-1}$ & 0.05 \\
\hline$V_{\mathrm{PN}}^{0}$ & & 0.1853 & & \\
\hline$V_{\mathrm{PN}}^{1}$ & & 0.1876 & & \\
\hline$C^{\lambda \mathrm{D}_{\mathrm{T}}}$ & $\begin{array}{l}\text { Temperature coefficient for } \\
\text { decomposition }\end{array}$ & 0.0693 & ${ }^{\circ} \mathrm{C}^{-1}$ & \\
\hline \multicolumn{5}{|c|}{ Carbon cycle model } \\
\hline$R_{\mathrm{P}: \mathrm{N}}$ & $\begin{array}{l}\text { Stoichiometry of nitrogen to } \\
\text { phosphorus }\end{array}$ & 16.0 & & \\
\hline$R_{\mathrm{C}: \mathrm{P}}$ & Molar elemental ratios & 112.0 & & \\
\hline$R_{\mathrm{CaCO}_{3}: \mathrm{POC}}$ & $\begin{array}{l}\mathrm{CaCO}_{3} \text { over nonphotosynthetical } \\
\text { POC production ratio }\end{array}$ & 0.00035 & & 0.035 \\
\hline$R_{\mathrm{ALK}: \mathrm{N}}$ & $\begin{array}{l}\text { Alkalinity over } \\
\text { nonphotosynthetical } \mathrm{N} \\
\text { production ratio }\end{array}$ & 0.001 & & \\
\hline$D_{\mathrm{CaCO}_{3}}$ & $\begin{array}{l}\mathrm{CaCO}_{3} \text { remineralization e-folding } \\
\text { depth }\end{array}$ & 3500.0 & $\mathrm{~m}$ & \\
\hline
\end{tabular}

model used here still simulates observed conditions well, capturing the basic seasonal variations of DIN, DIP, DIC, and ALK in comparison with the climatological and in situ data (Figs. 1, 2, 3, 4, and 5). Although the satellite data in the subarctic region exhibit distinctive double peaks in spring and autumn (Fig. 5(a)), the concentration of Chla given by the model shows only a single peak in summer in the subarctic region (Figs. 1 and 5(a, d)). Ishizu et al. (2019) suggested that this single peak in summer is caused by a lack of iron restriction (Tsuda et al. 2003) of the model. The seasonal variabilities in DIN and DIC in the model outputs are represented well (Fig. 2(g, h) and the $50^{\circ} \mathrm{N}$ line in Fig. 5(e)) compared to the DIN and DIC climatology (Figs. 2(c, d) and $5(\mathrm{c}-\mathrm{e})$ ). It is difficult to judge whether the distribution of ALK is accurate, but modeled ALK concentrations are generally constant throughout the year (Fig. 4(d-g)) and are consistent with JMA observations (Fig. 4(a-c)).

The reproducibility of the model is poorer than that of Ishizu et al. (2019) for DIN and DIC (Table 2), but the reproducibility of ALK is much improved, especially in the subarctic region, the Kuroshio Extension, and the Japan Sea. The correlation between observed ALK and simulated ALK is low and negative $(R=-0.24)$ in the Japan Sea because the simulated ALK values there have near-uniform values with depth (not shown).

\subsection{Ocean acidification indices $\mathrm{pH}_{\text {in situ, }} \mathrm{pH}_{25}$, and $\boldsymbol{\Omega}_{\text {arg }}$}

The ocean acidification indices $\mathrm{pH}_{\text {in situ }}, \mathrm{pH}_{25}$, and aragonite saturation $\left(\Omega_{\text {arg }}\right)$ were calculated from model results for temperature, salinity, DIC, and ALK. The $\mathrm{pH}_{\text {in situ }}$ values change throughout the year (Figs. 6 and 7). The summer $\mathrm{pH}_{\text {in situ }}$ values in the subarctic region $\left(150-175^{\circ} \mathrm{E}, 50-60^{\circ} \mathrm{N}\right)$ are slightly higher $(8.05-8.10)$ than those shown in Fig. 9 of Ishizu et al. (2019); 7.95-8.00; Figs. 6(a-d) and 7a). Summer $\mathrm{pH}_{\text {in situ }}$ values for regions north of $35^{\circ}$ 

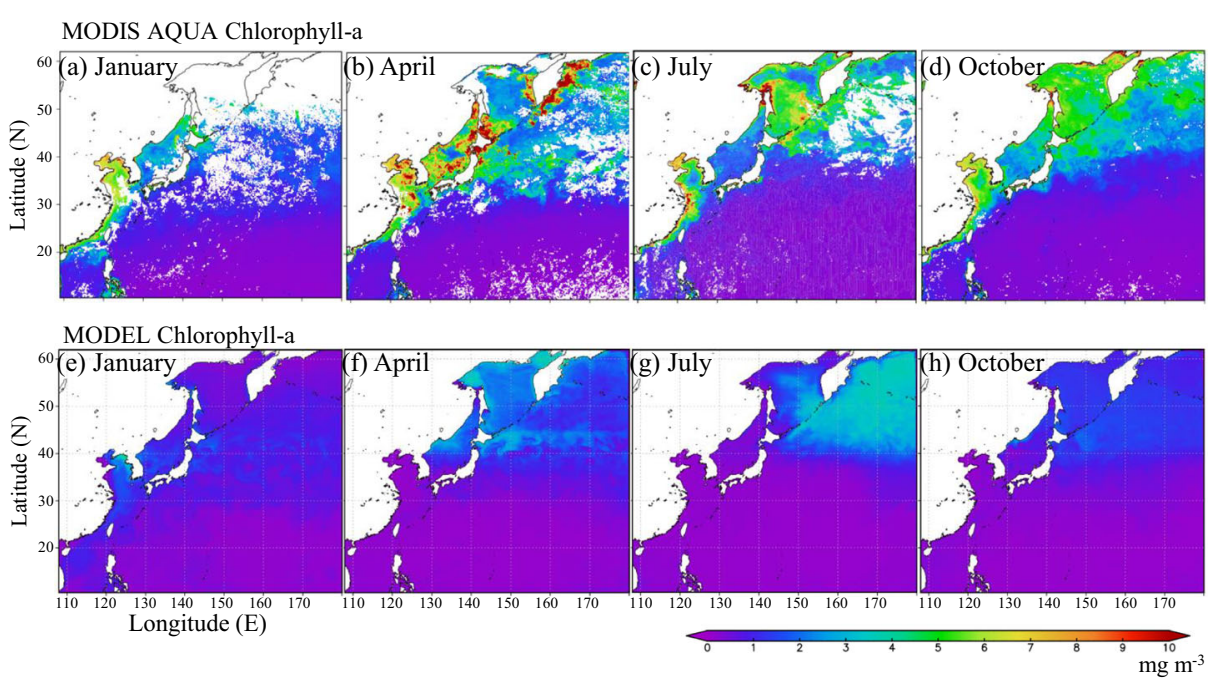

Fig. 1 Surface distribution of monthly mean chlorophyll-a (Chl-a) concentrations from MODIS_Aqua data and from model outputs (this study) for January (a, e), April (b, f), July (c, g), and October (d, h). Conversion from phytoplankton to Chl-a values was performed using a weight ratio of carbon to chlorophyll-a of C:Chl-a $=40: 1$ (Li et al. 2010; Stelmakh and Gorbunova 2018) and a ratio of C:N = 106:16 (Redfield et al. 1963)

$\mathrm{N}$ decreased by 0.05 from winter to summer (Figs. $6(\mathrm{a}-\mathrm{d})$ and $7 \mathrm{a})$. The general seasonal variability is consistent with the previous model version used by Ishizu et al. (2019).

Horizontal distributions of $\mathrm{pH}_{25}$ exhibit consistent seasonal variability across all latitudes (Figs. 6(e-h) and $7 \mathrm{~b}$ ) but with different amplitudes. The $\mathrm{pH}_{25}$ values at higher latitudes are lower than at lower latitudes, with an increase of 0.15 in summer. Their amplitudes gradually decrease southward. The $\mathrm{pH}_{25}$ values in the subtropical region south of $20^{\circ} \mathrm{N}$ are generally constant throughout the year.
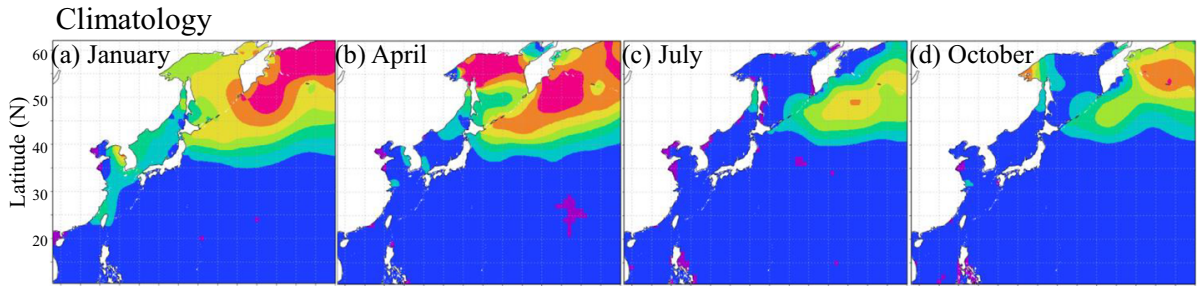

Model outputs
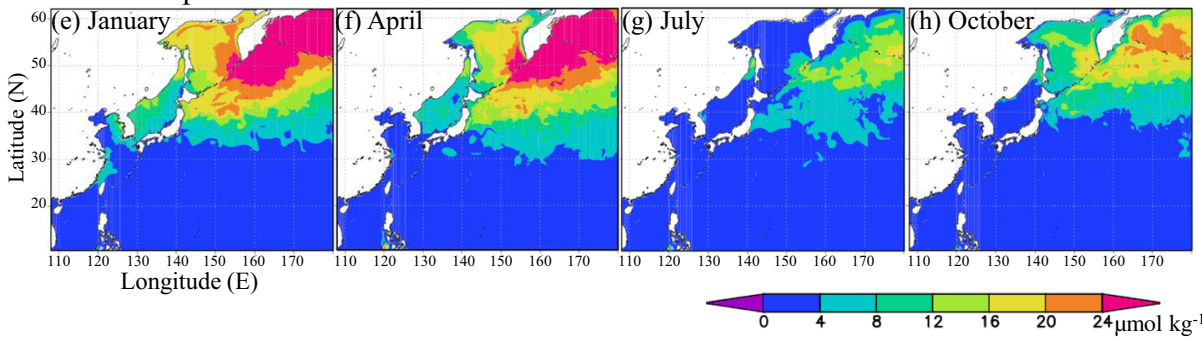

Fig. 2 Surface monthly distributions of dissolved inorganic nitrate (DIN: $\mu \mathrm{mol} \mathrm{kg}^{-1}$ ) for January (a, e), March (b, f), July (c, g), and October (d, h) from climatology from WOA13 and Yasunaka et al. (2014) and model outputs, respectively 


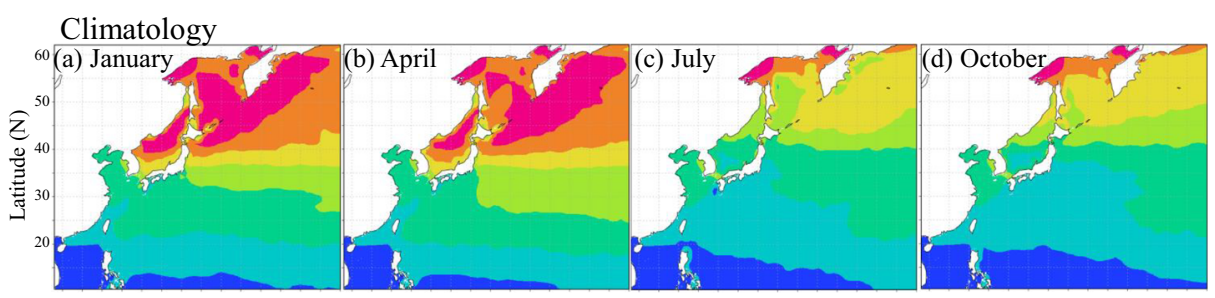

Model outputs

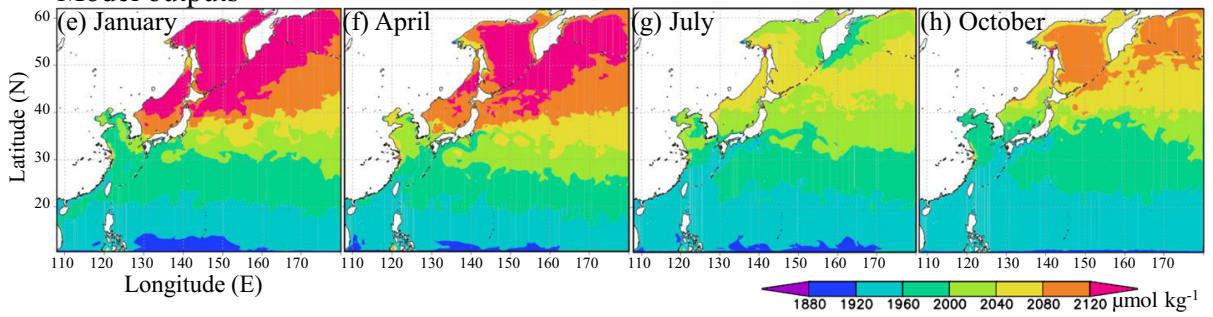

Fig. 3 Surface monthly distributions of dissolved inorganic carbon (DIC: $\mu \mathrm{mol} \mathrm{kg}^{-1}$ ) for January (a, e), April (b, f), July (c, g), and October (d, h) from climatology and model outputs, respectively. The climatology was obtained by combining the datasets of Goyet et al. (2009), Key et al. (2014), and Yasunaka et al. (2014) (see Section 3.1 for details)

The seasonal pattern of $\Omega_{\text {arg }}$ (Fig. 6(i-l)) is similar to that of $\mathrm{pH}_{25}$ (Fig. 6(e-h)). The $\Omega_{\text {arg }}$ values in the same area of $\mathrm{pH}_{25}$ north of $35^{\circ} \mathrm{N}$ become $0.5-1.0$ larger in summer and in autumn. The summer increase in $\Omega_{\text {arg }}$ is less evident in the south.

Correlation coefficients for modeled $\mathrm{pH}_{\text {in situ }}, \mathrm{pH}_{25}$, and $\Omega_{\text {arg }}$ are higher than those reported by Ishizu et al. (2019) because the accuracy of the modeled ALK concentrations is much improved compared to them.

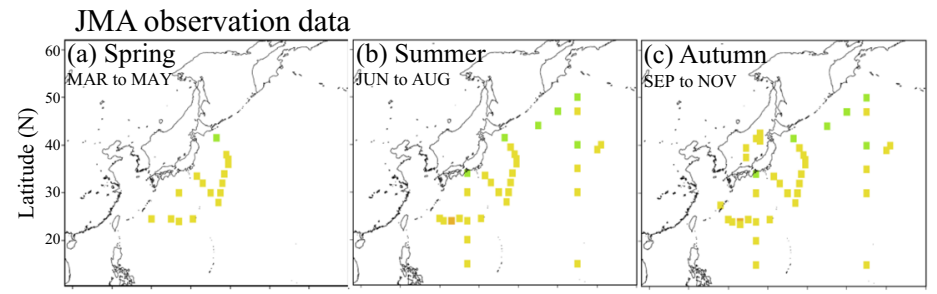

Model outputs

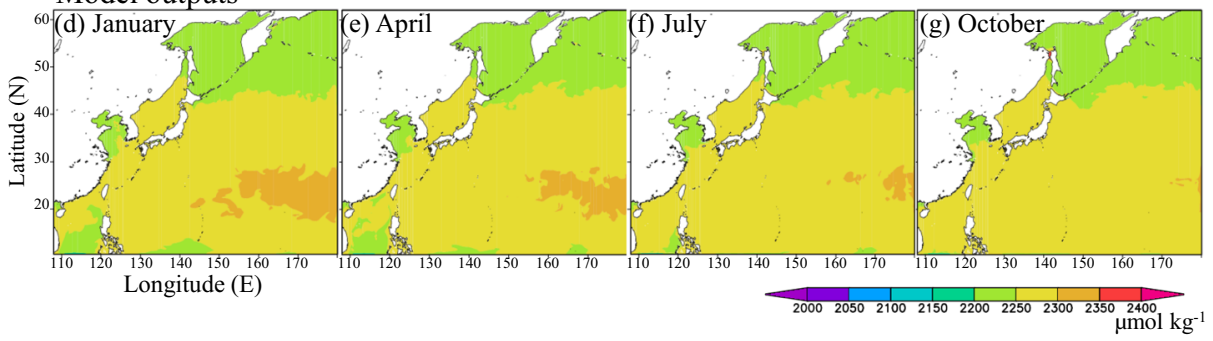

Fig. 4 Plots of JMA observation values of total alkalinity averaged above $20 \mathrm{~m}$ depth in spring (a; March to May), summer (b; June to August), and autumn (c; September to November). Surface monthly distributions of total alkalinity (ALK: $\mu \mathrm{mol} \mathrm{kg} \mathrm{kg}^{-1}$ ) for January (d), April (e), July (f), and October (g) in model outputs. All figure panels use the same color bar to denote values 


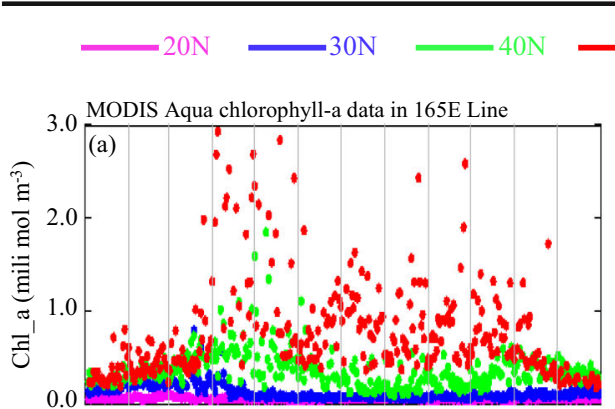

$50 \mathrm{~N}$

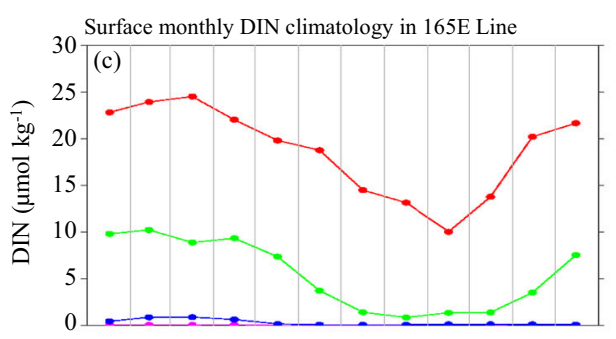

Model outputs of surface chlorophyll-a data in 165E Line

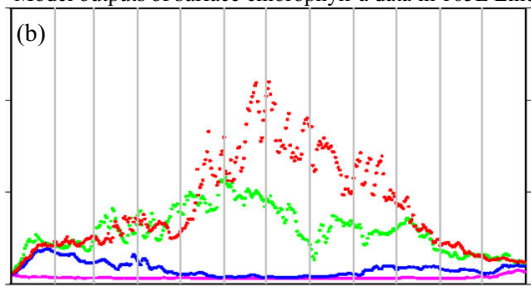

Model outputs of surface DIN in 165E Line
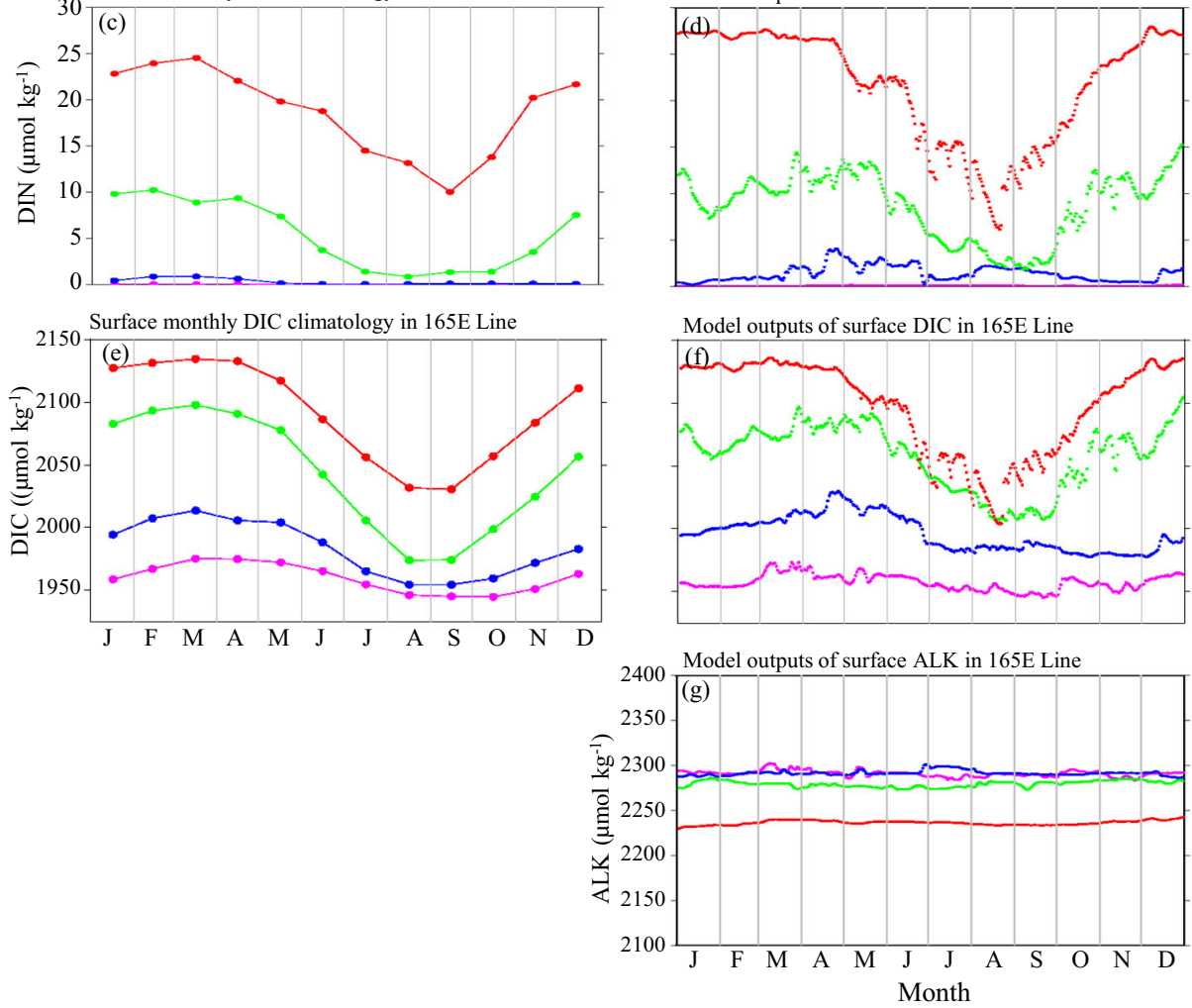

Fig. 5 Time series of surface chlorophyll-a, DIN, DIC, and ALK data along $165^{\circ} \mathrm{E}$ from model outputs. Purple, blue, green, and red colors depict data for $20^{\circ} \mathrm{N}, 30^{\circ} \mathrm{N}, 40^{\circ} \mathrm{N}$, and $50^{\circ} \mathrm{N}$, respectively

\section{Discussion}

\subsection{Processes affecting the seasonal inorganic carbon cycle}

To identify processes affecting the inorganic carbon cycle, we examined the physical and biological mechanisms underlying the seasonal inorganic carbon cycle in the Northwest Pacific using the model results. We separately evaluate each process included in the governing equation as follows: 
Table 2 Correlation coefficients $(R)$ in chlorophyll-a (Chl-a), DIN, DIC, alkalinity, pH 25, and $\Omega_{\text {arg }}$ between observed data and model outputs in 2015 for each region (Fig. 1). The left and middle values in a column indicate $R$ and the $95 \%$ confidence interval for $R$, respectively. Values in brackets indicate $p$ values relative to a significance level of 0.05 . Chl-a values are expressed by using the common logarithm, log10(Chl-a). Italic and bold values indicate the areas of lower and higher and correlation coefficients, respectively, compared with those given by Ishizu et al. (2019)

\begin{tabular}{|c|c|c|c|c|}
\hline Parameter & Subtropical region & Subarctic region & Kuroshio extension & Japan Sea \\
\hline Chlorophyll-a & $\begin{array}{l}0.67 ; 0.63<\mathrm{R}<0.70 \\
\quad(0.07)\end{array}$ & $\begin{array}{l}0.83 ; 0.79<R<0.87 \\
\quad(0.07)\end{array}$ & $\begin{array}{l}0.80 ; 0.75<R<0.84 \\
\quad(0.12)\end{array}$ & $0.92 ; 0.89<\mathrm{R}<0.94(0.15)$ \\
\hline DIN & $\begin{array}{l}0.61 ; 0.57<R<0.65 \\
\quad(0.04)\end{array}$ & $\begin{array}{l}0.87 ; 0.83<R<0.90 \\
\quad(0.12)\end{array}$ & $\begin{array}{l}0.84 ; 0.81<\mathrm{R}<0.87 \\
\quad(0.10)\end{array}$ & $\begin{array}{l}0.94 ; 0.92<R<0.95 \\
\quad(0.11)\end{array}$ \\
\hline DIC & $\begin{array}{l}0.69 ; 0.64<R<0.74 \\
\quad(0.09)\end{array}$ & $\begin{array}{l}0.87 ; 0.81<\mathrm{R}<0.91 \\
\quad(0.20)\end{array}$ & $\begin{array}{l}0.72 ; 0.79<R<0.89 \\
\quad(0.17)\end{array}$ & $0.95 ; 0.92<R<0.97(0.26)$ \\
\hline Alkalinity & $\begin{array}{l}0.39 ; 0.31<R<0.47 \\
\quad(0.09)\end{array}$ & $\begin{array}{l}0.88 ; 0.83<\mathrm{R}<0.92 \\
\quad(0.20)\end{array}$ & $\begin{array}{l}0.63 ; 0.51<\mathrm{R}<0.72 \\
\quad(0.17)\end{array}$ & $\begin{array}{l}-0.24 ;-0.47<R<0.02 \\
\quad(0.26)\end{array}$ \\
\hline $\mathrm{pH}_{25}$ & $\begin{array}{l}0.81 ; 0.77<\mathrm{R}<0.84 \\
\quad(0.09)\end{array}$ & $\begin{array}{l}0.88 ; 0.82<\mathrm{R}<0.92 \\
\quad(0.20)\end{array}$ & $\begin{array}{l}0.89 ; 0.92<\mathrm{R}<0.95 \\
(0.17)\end{array}$ & $0.94 ; 0.90<R<0.96(0.26)$ \\
\hline$\Omega_{\text {arg }}$ & $\begin{array}{c}0.99 ; 0.994<\mathrm{R}<0.995 \\
(0.09)\end{array}$ & $\begin{array}{l}0.98 ; 0.978<\mathrm{R}<0.986 \\
\quad(0.20)\end{array}$ & $\begin{array}{l}0.99 ; 0.987<R<0.991 \\
\quad(0.17)\end{array}$ & $\begin{array}{l}0.99 ; 0.985<\mathrm{R}<0.993 \\
\quad(0.26)\end{array}$ \\
\hline
\end{tabular}
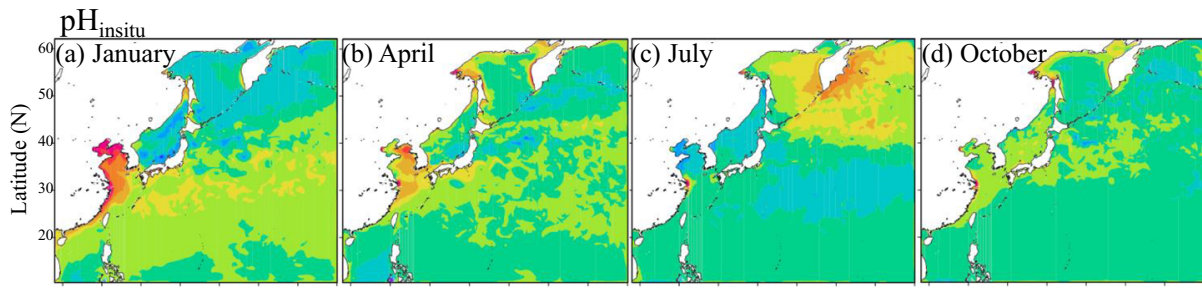

$\mathrm{pH}_{25}$
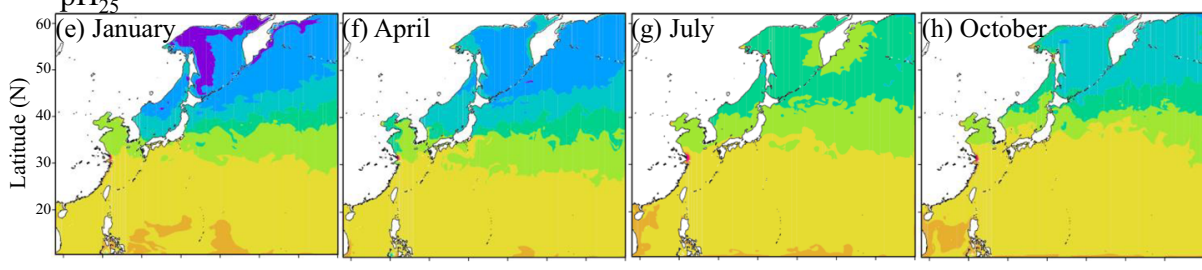

Aragonite saturation $\left(\Omega_{\mathrm{arg}}\right)$
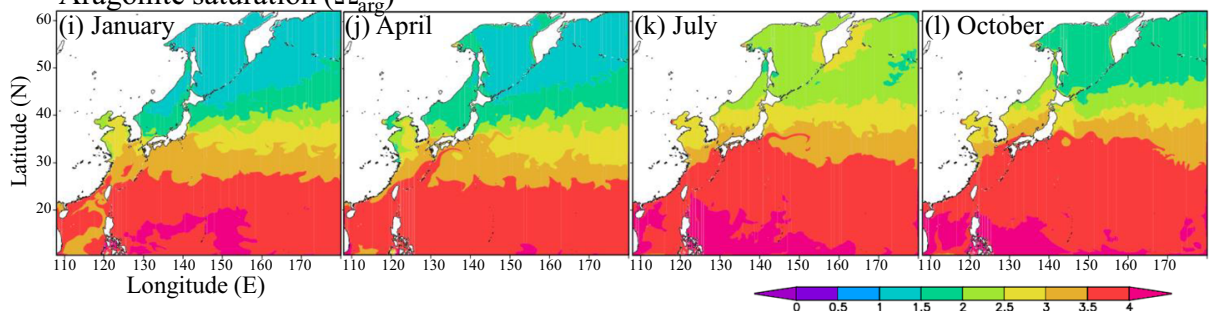

Fig. 6 Surface monthly distributions of $\mathrm{pH}_{\mathrm{in} \mathrm{situ}}, \mathrm{pH}_{25}$, and aragonite saturation $\left(\Omega_{\mathrm{arg}}\right)$ for January (a, e, i, m), March (b, f, j, n), July (c, g, k, o), and October (d, h, l, p) from model outputs, respectively 

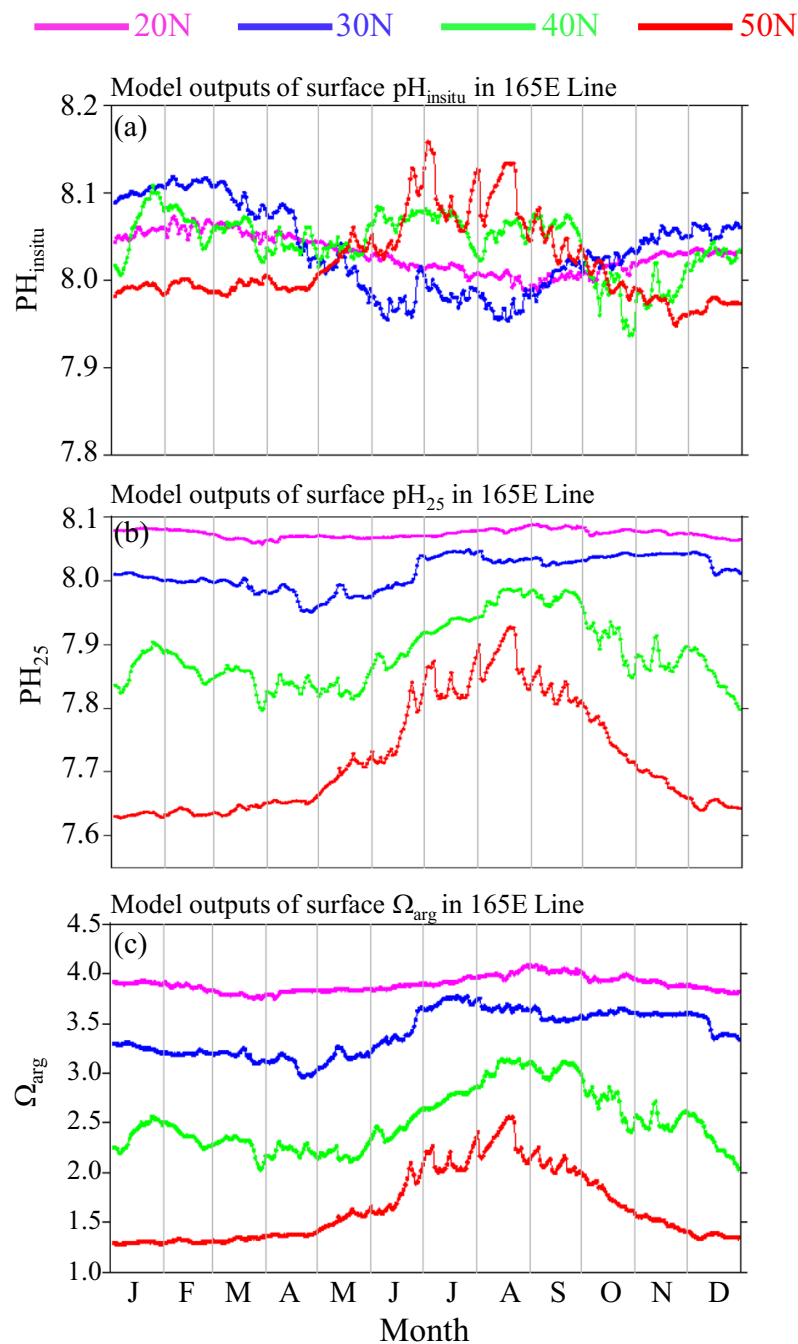

Fig. 7 Time series of surface $\mathrm{pH}_{\text {in situ }}(\mathbf{a}), \mathrm{pH}_{25}(\mathbf{b})$, and $\Omega_{\text {arg }}$ (c) along $165^{\circ} \mathrm{E}$ from model outputs. Purple, blue, green, and red colors depict data for $20^{\circ} \mathrm{N}, 30^{\circ} \mathrm{N}, 40^{\circ} \mathrm{N}$, and $50^{\circ} \mathrm{N}$, respectively

$$
\frac{\partial[\mathrm{DIC}]}{\partial t}=\left[\frac{\partial[\mathrm{DIC}]}{\partial t}\right]_{\mathrm{A}}+\left[\frac{\partial[\mathrm{DIC}]}{\partial t}\right]_{x y_{\text {dif }}}+\left[\frac{\partial[\mathrm{DIC}]}{\partial t}\right]_{z_{\text {_dif }}}+\left[\frac{\partial[\mathrm{DIC}]}{\partial t}\right]_{\mathrm{Bio}}+\left[\frac{\partial[\mathrm{DIC}]}{\partial t}\right]_{\text {air }- \text { sea }}
$$

where the subscripts A, xy_dif, z_dif, Bio, and air-sea represent the time derivatives of DIC induced by advection, horizontal diffusion (i.e., horizontal mixing), vertical mixing, biological processes, and air-sea $\mathrm{CO}_{2}$ exchange (positive values indicate a transfer of $\mathrm{CO}_{2}$ from air to sea), respectively. Note that we refer to these as "DIC variation terms" here, and the DIC variations induced by air-sea $\mathrm{CO}_{2}$ exchange are included only for the top (surface) level and not for the levels below it. The total DIC variation term on the left side of Eq. (7) is a summation of all the terms on the right-hand side of the equation. 
Air-sea $\mathrm{CO}_{2}$ exchange shows negative values $\left(\mathrm{CO}_{2}\right.$ emission to the atmosphere) in winter north of $35^{\circ} \mathrm{N}$ (Fig. 8(a)) and positive values $\left(\mathrm{CO}_{2}\right.$ absorption from the atmosphere) south of $35^{\circ} \mathrm{N}$, and vice versa in summer for these regions. The subarctic region releases $\mathrm{CO}_{2}$ to the atmosphere in winter north of $35^{\circ} \mathrm{N}$ (Fig. 8(a)), and absorbs $\mathrm{CO}_{2}$ from the atmosphere in summer north of $35^{\circ} \mathrm{N}$ (Fig. 8(c)). In contrast, the subtropical region south of $35^{\circ} \mathrm{N}$ intensely absorbs $\mathrm{CO}_{2}$ south of the Kuroshio Extension in winter (Fig. 8(a)). A weak release of $\mathrm{CO}_{2}$ from the ocean to the atmosphere occurs south of $40^{\circ} \mathrm{N}$ in summer. The areas of strongest release are located in the northeast of the Kuril Islands in the Oyashio region and in the Okhotsk Sea in autumn-winter (Fig. 8(a, d)). (Further details on air-sea $\mathrm{CO}_{2}$ exchange represented in the model are described in the Appendix.)

Horizontal distributions and monthly mean balances of the DIC variation terms in the surface layer induced by all subprocesses (Figs. 8 and $9(\mathrm{a}-\mathrm{d})$ ) indicate that the air-sea $\mathrm{CO}_{2}$ exchange shown in Fig. $8(\mathrm{a}-\mathrm{d})$ is generally offset by vertical mixing. Biological processes, however, made a subordinate contribution to the total DIC variation (Figs. 8 and $9(\mathrm{c}, \mathrm{d}, \mathrm{g}, \mathrm{h}, \mathrm{j}, \mathrm{k}, \mathrm{m})$ ). Negative biological process values indicate consumption of DIC through photosynthesis. Biological process contributions vary spatially and with depth (Figs. 8 and 9; Appendix Figs. 16-18). At the surface level, the DIC consumption induced by biological processes is high in the subarctic region around $50^{\circ} \mathrm{N}$ throughout the year (Figs. $8(\mathrm{~m}-\mathrm{p})$ and $9(\mathrm{a}-\mathrm{d})$ ). The peak consumption of DIC moves deeper beneath the surface southward (Fig. 9(d, e-g, j, $\mathrm{m}$ ); Appendix Figs. 17 and 18). The highest DIC consumption occurs at 50-100 m depth at $30-40^{\circ} \mathrm{N}$ (Fig. 9(g, j, k); Appendix Figs. 16(m-p) and 17(m-p)) and at $200 \mathrm{~m}$ depth in the subtropical region south of $30^{\circ} \mathrm{N}$ (Fig. 9(m); Appendix Fig. $18(\mathrm{~m}-\mathrm{p}))$. The contributions from biological processes at the surface and at $200 \mathrm{~m}$ depth are of opposite sign (Fig. 8(m-p); Appendix Fig. 18(m-p)). Instead of the contributions of the vertical mixing or biological processes below the surface, we see that advection processes are relatively contributed to the total DIC variation (Fig. 9(i$\mathrm{k}, \mathrm{n}, \mathrm{m})$ ).

The relative contribution of biological processes compared with the other terms at $165^{\circ} \mathrm{E}$ is calculated as

relative contribution

$$
=\frac{\Delta \mathrm{DIC}_{\text {Bio }}}{\left|\Delta \mathrm{DIC}_{A}\right|+\left|\Delta \mathrm{DIC}_{x y \_ \text {dif }}\right|+\left|\Delta \mathrm{DIC}_{z_{\text {_dif }}}\right|+\left|\Delta \mathrm{DIC}_{\text {Bio }}\right|+\left|\Delta \mathrm{DIC}_{\text {air-sea }}\right|} \times 100 \%
$$

as shown in Fig. 10. The highest DIC consumption occurs above $100 \mathrm{~m}$ depth north of $40^{\circ} \mathrm{N}$ throughout the year, gradually deepening in the range $30-40^{\circ} \mathrm{N}$, and spreading vertically at $100-350 \mathrm{~m}$ depth in the subtropical region at latitudes south of $30^{\circ} \mathrm{N}$. These patterns of DIC consumption/production may be caused by the latitudinal difference of the Chl-a maximum depth (Ishizu et al. 2019; Sauzede et al. 2015). Vertical distributions of Chl-a along $165^{\circ} \mathrm{E}$ from Ishizu et al. (2019) and global ocean Chl-a data from Sauzede et al. (2015) indicate that the Chl-a maximum deepens southward; the Chl-a maximum is located in the surface layer in subarctic regions and at $\sim 150 \mathrm{~m}$ depth in subtropical regions. The highest $\mathrm{Chl}$-a consumption in the subtropical region from our results (Fig. 10) occurs at greater depths (200-500 m), but the magnitude is relatively low and makes a negligible contribution to the total variation in DIC (Fig. 9(n-p)). 
DIC variation term induced by air-sea $\mathrm{CO}_{2}$ exchange
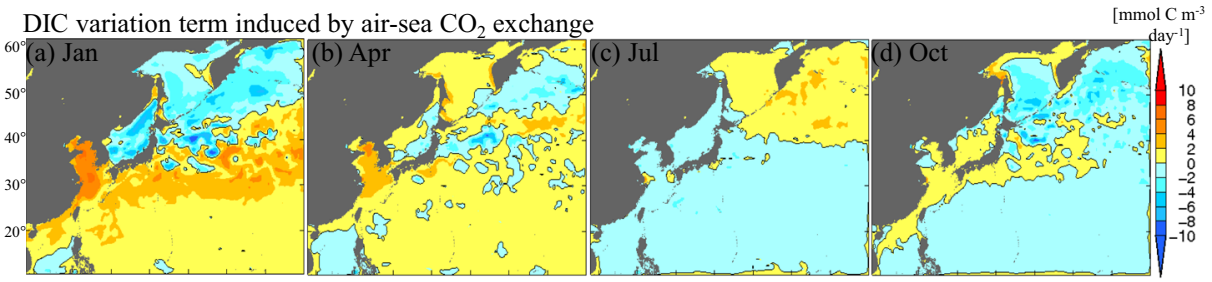

DIC variation term induced by advection effect

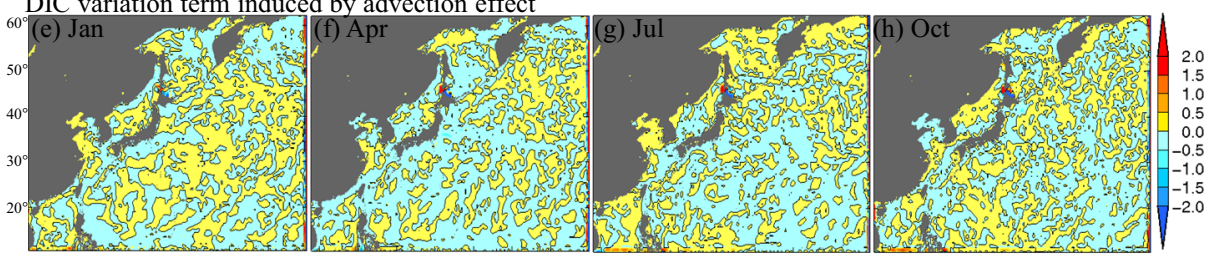

DIC variation term induced by vertical mixing

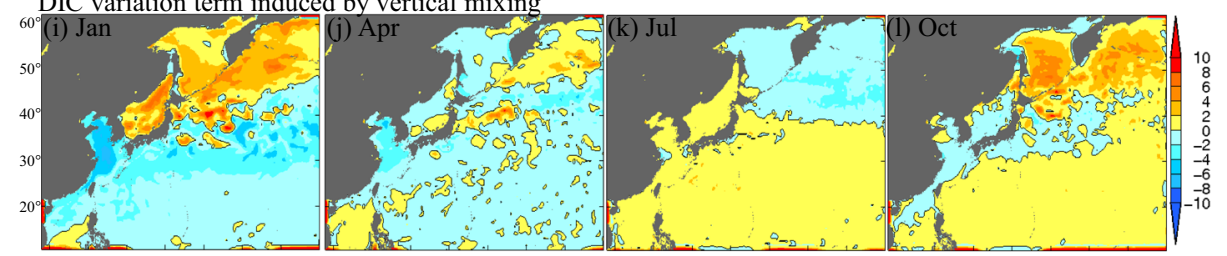

DIC variation term induced by biological processes

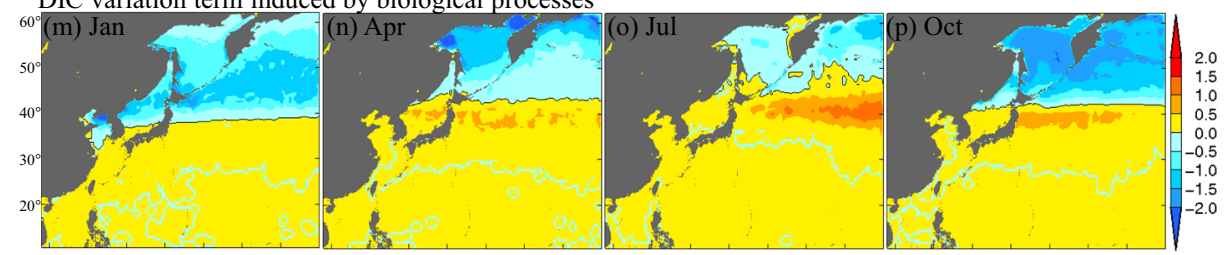

Total DIC time variation term

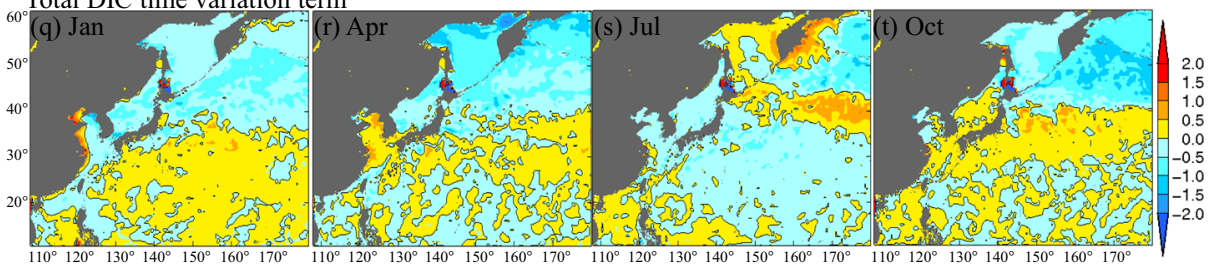

Fig. 8 Surface horizontal distributions of monthly mean DIC variation terms generated by air-sea $\mathrm{CO}_{2}$ exchange to the ocean $(\mathrm{a}-\mathrm{d})$, advection $(\mathrm{e}-\mathrm{h})$, vertical mixing $(\mathrm{i}-\mathrm{l})$, biological processes $(\mathrm{m}-\mathrm{p})$, and total DIC time variation terms $(q-t)$ at the surface $(0 \mathrm{~m}$ depth) for January, April, July, and October, respectively

\subsection{Mechanisms of the seasonal inorganic carbon cycle}

The relative contributions of terms in the governing equation of DIC (Figs. 8 and 9; Appendix Figs. 16-18) suggest possible mechanisms for the seasonal carbon cycle, as follows. $\mathrm{CO}_{2}$ (DIC) is absorbed from the atmosphere to the ocean during winter south of $40^{\circ} \mathrm{N}$. The corresponding absorbed volume of DIC is conveyed from the surface to the subsurface by vertical mixing (Figs. 8(i, j) and $9(\mathrm{a}-\mathrm{c})$ ). In summer and autumn, $\mathrm{CO}_{2}(\mathrm{DIC})$ is released to the atmosphere by air-sea interactions, and vertical mixing generally offsets carbon emissions 


$$
\begin{aligned}
& \frac{\partial[D I C]}{\partial t}=\left[\frac{\partial[D I C]}{\partial t}\right]_{A}+\left[\frac{\partial[D I C]^{2}}{\partial t}\right]_{x y_{-} d i f}+\left[\frac{\partial[D I C]}{\partial t}\right]_{z_{-} \text {dif }}+\left[\frac{\partial[D I C]}{\partial t}\right]_{B i o}+\left[\frac{\partial[D I C]}{\partial t}\right]_{\text {air-sea }} \\
& \Delta \text { DIC Advection Horizontal mixing Vertical mixing Biological processes Air-sea exchange }
\end{aligned}
$$
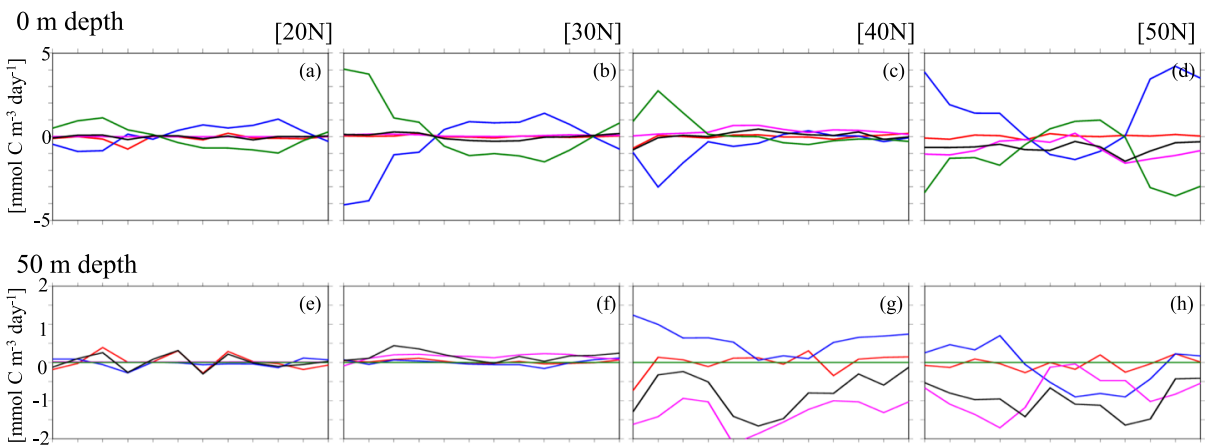

$100 \mathrm{~m}$ depth
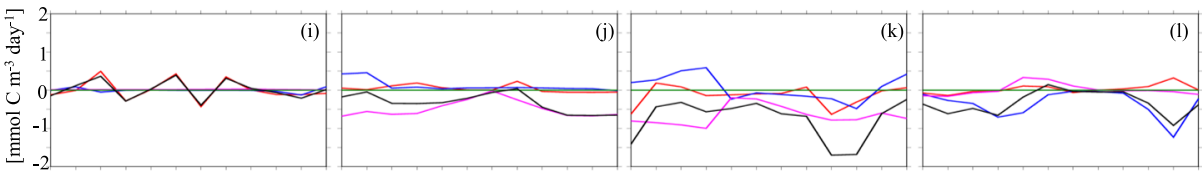

$200 \mathrm{~m}$ depth
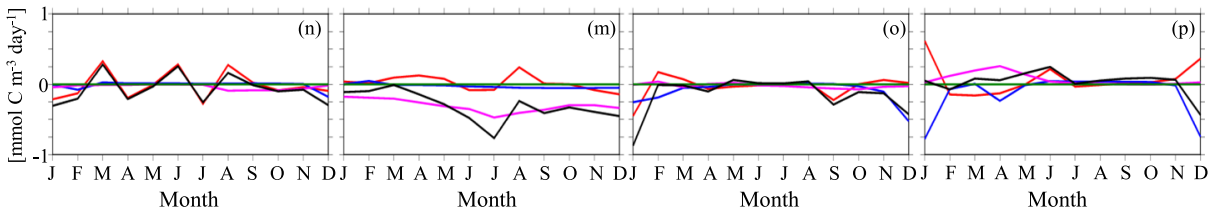

Fig. 9 Monthly mean balances of DIC variation terms $\left(m m o l ~ \mathrm{C} \mathrm{m}^{-3} \mathrm{day}^{-1}\right)$ along $165^{\circ} \mathrm{E}$ for $20^{\circ} \mathrm{N}, 30^{\circ} \mathrm{N}, 40^{\circ}$ $\mathrm{N}$, and $50^{\circ} \mathrm{N}$ at depths of $0,50,100$, and $200 \mathrm{~m}$. The monthly mean values were calculated within a range of five grid cells $(22.0-45.5 \mathrm{~km})$ from the target location. Colored lines indicate monthly means of the processes of DIC variation terms $(\triangle D I C)$ induced by advection, horizontal mixing, vertical mixing, biological processes, and airsea exchange process, and total DIC time variation (from Eq. 7). Positive and negative values indicate an increase and decrease in each DIC time variation term, respectively. The DIC variation term influenced by air-sea $\mathrm{CO}_{2}$ exchange is considered only for the surface $(a-d)$, not below it $(e-p)$, where the green line representing zero is given as a reference for the other terms

(Figs. 8(c, d) and $9(\mathrm{a}-\mathrm{c}))$. In the subarctic region, this interaction is opposite that in the subtropical region (Figs. $8(\mathrm{a}-\mathrm{k})$ and $9(\mathrm{a}-\mathrm{d})$ ), with a negative contribution from biological processes (i.e., a sink) throughout the year (Figs. $8(\mathrm{~m}-\mathrm{p})$ and $9(\mathrm{a}-\mathrm{d}))$. Below $50 \mathrm{~m}$ depth, the advection term becomes more prominent in the subtropical region and in the Kuroshio

${ }_{0}$ (a) Jan

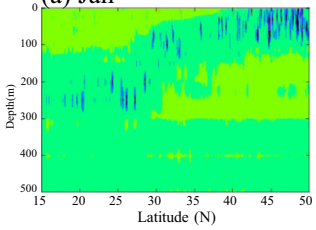

(b) Apr

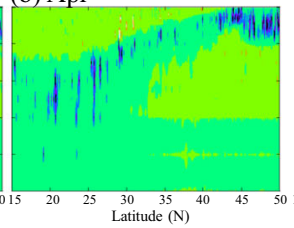

(c) Jul

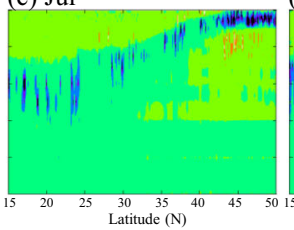

(d) Oct

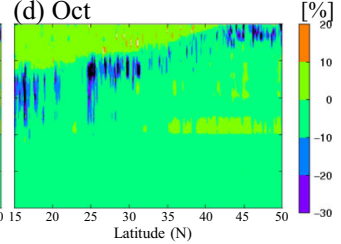

Fig. 10 Vertical sections showing the relative contribution of biological processes to total DIC time variation along $165^{\circ} \mathrm{E}$ (from Eq. 7) for January, April, July, and October. Positive and negative percentages indicate the production and consumption of DIC induced by biological processes, respectively 
Extension region, connecting with total DIC time variation (Fig. 9(i-k, n, m)). Working against the small negative contribution of biological processes below $200 \mathrm{~m}$ depth in our model (Fig. 9(n-p)) is advection, which can produce an increase or decrease in DIC in the subtropical region (Fig. 9(n)).

The modeled carbon cycle also includes latitudinal differences in total DIC time variation, as shown in Figs. 12 and 13(a). Differences in the contribution from biological processes are related to the total DIC time variation both horizontally and vertically (Figs. 12 and 13(a)). A distinctive area of DIC decrease exists near 0-200 $\mathrm{m}$ depth, and deepens southward from the subarctic region to the subtropical region (Figs. 11(a-d) and 12b). A comparison between the annual mean DIC time variation and the Chl-a maximum depth (Ishizu et al. 2019; Fig. 12) shows some similarity above $200 \mathrm{~m}$ depth. Advection dominates the trend in annual mean DIC time variation in the subtropical region south of $30^{\circ} \mathrm{N}$ below $200 \mathrm{~m}$ depth (Fig. 9(n)). These results suggest that the positive and negative patterns of annual mean DIC time variation are caused by ocean currents (Fig. 9(n)).

The density range of this distinctive zone of contrast is comparable with that of the North Pacific Ocean Central Mode Water (CMW; $\sigma_{\theta}=26.0-26.5 \mathrm{~kg} \mathrm{~m}^{-3}$; Oka and Suga 2005; Oka and Qui 2012; Fig. 12b). Those waters are formed by winter ventilation around thermocline fronts, including the Kuroshio Extension front, the Kurhoshio Bifurcation front, and the subarctic front, and are then spread by advection (Oka and Suga 2005; Oka and Qui 2012). We therefore suggest that the positive and negative contrast in the temporal DIC variations depends on uptake in the ventilation areas north of $40^{\circ} \mathrm{N}$ and could be transported by advection (Fig. 12). A sensitivity experiment was performed in which the maximum depth of Chl-a was decreased by adjusting the biological parameters related to photosynthesis $\left(I_{\mathrm{op}}\right)$, to check whether advection affects the contrast in DIC time variation below the surface layer. Features of the DIC time variation south of $25^{\circ} \mathrm{N}$ were almost identical in the base and sensitivity experiments (not shown), supporting the dominant role of advection in the subtropical region.

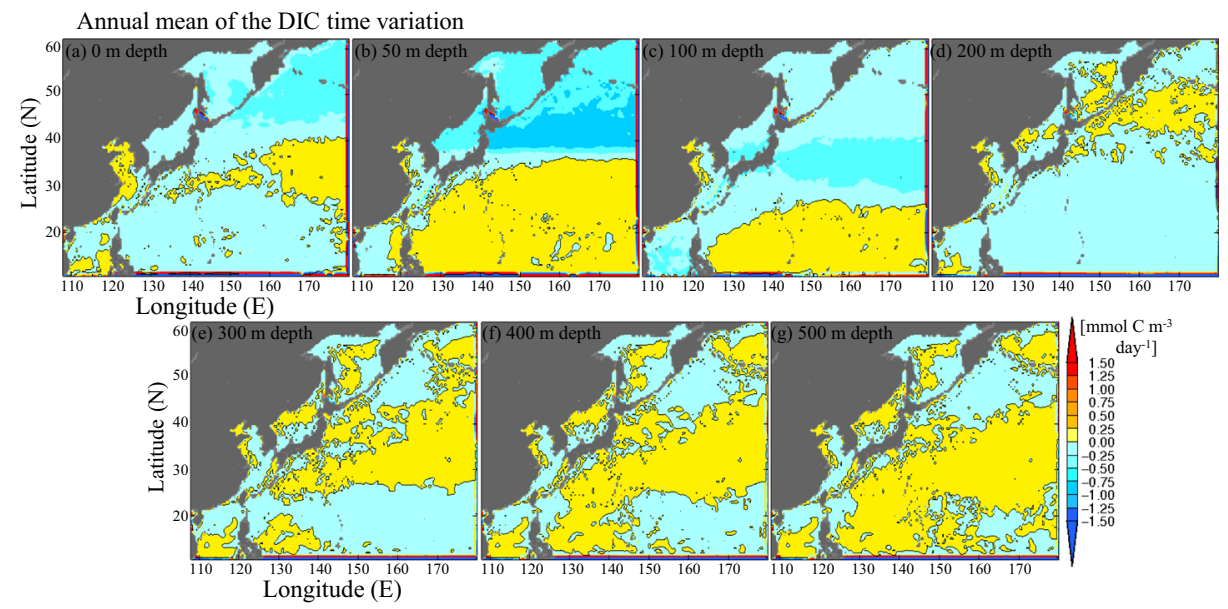

Fig. 11 Horizontal distributions of the annual mean DIC time variation at depths of $0 \mathrm{~m}$ (a), $50 \mathrm{~m}$ (b), $100 \mathrm{~m}$ (c), $200 \mathrm{~m}(\mathrm{~d}), 300 \mathrm{~m}(\mathrm{e}), 400 \mathrm{~m}$ (f), and $500 \mathrm{~m}(\mathrm{~g})$. Positive and negative values indicate an increase and decrease in each DIC time variation term, respectively 

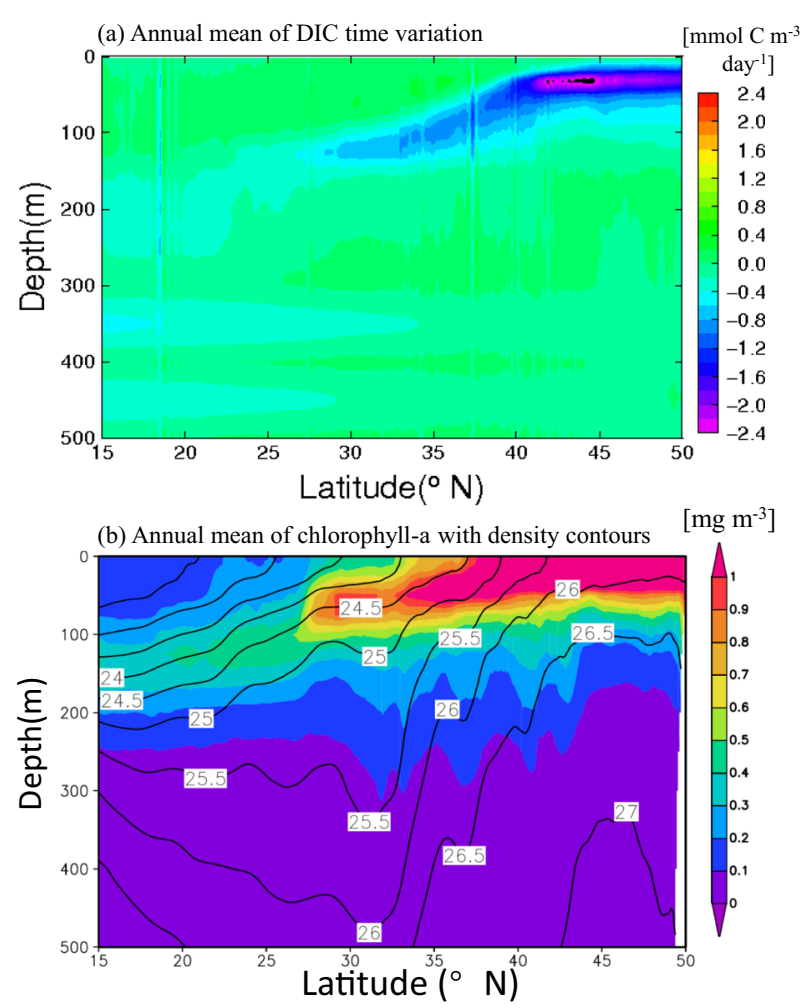

Fig. 12 Vertical distributions of the annual mean of DIC time variation $\left(\mathbf{a} ; \mathrm{mmol} \mathrm{C} \mathrm{m}^{-3}\right.$ day $\left.^{-1}\right)$ and of chlorophyll-a $\left(\mathbf{b} ; \mathrm{mg} \mathrm{m}^{-3}\right)$ along $165^{\circ} \mathrm{E}$. Vertical distributions of colored chlorophyll-a in $\mathbf{b}$ are also shown with contours of potential density, $\sigma_{\theta}\left(\mathrm{kg} \mathrm{m}^{-3}\right)$

\subsection{Comparison with previous work on the marginal seas}

The balance of the monthly mean DIC time variation terms in the East China and Japan seas (Fig. 13(a, b)) shows that air-sea $\mathrm{CO}_{2}$ exchange is generally offset by vertical mixing. These balances differ from the simulation results for the Yellow and East China Seas of Luo et al. (2015), which indicates that the contributions of vertical mixing, advection, and biological processes to the inorganic carbon cycle largely offset each other on the continental shelves and vary seasonally. The difference between the results of Luo et al. (2015) and those presented here may be due to missing processes in our model that may be required to represent local variability in these regions (e.g., the DIC input from river discharge), although the reproducibilities for the Japan and East China seas are high, with high correlation coefficients for several variables, including Chl-a, DIN, DIC, $\mathrm{pH}_{25}$, and $\Omega_{\text {arg }}$ (Table 2).

The reproducibility for the Okhotsk Sea could not be evaluated because of a lack of observational data. Variations in DIC in Okhotsk Sea simulated by our model (Fig. 13(c)) are similar to those for the subarctic region of the Northwest Pacific, where the contributions of air-sea $\mathrm{CO}_{2}$ exchange and vertical mixing are generally offset by each other (Fig. 13(c)) and biological processes make a subordinate contribution.

The relatively small contribution of biological processes in the DIC cycle in marginal seas can be explained by the latitude-dependent functions of biological 


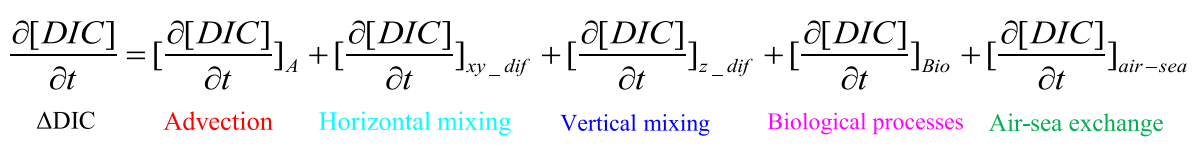

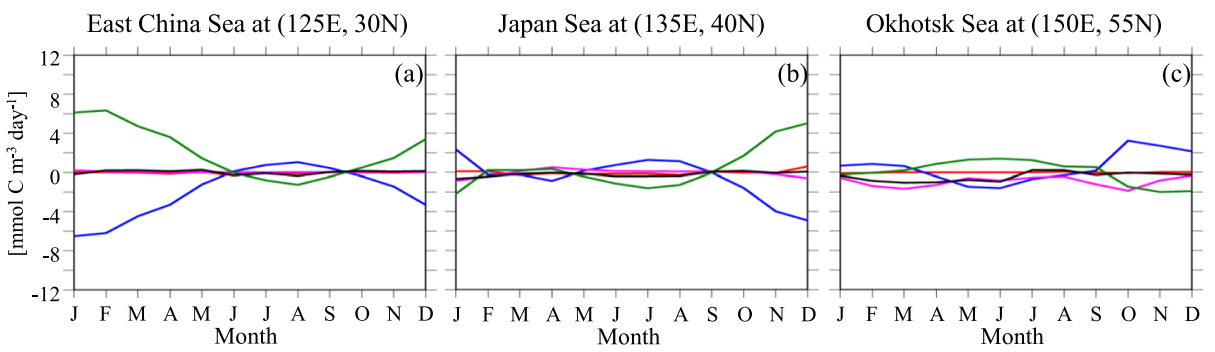

Fig. 13 The same as in Fig. 9 but for the monthly mean balance of each DIC term in the surface layer (at $0 \mathrm{~m}$ depth) in the East China Sea $\left(30^{\circ} \mathrm{N}, 125^{\circ} \mathrm{E}\right)$, the Japan Sea $\left(40^{\circ} \mathrm{N}, 135^{\circ} \mathrm{E}\right)$, and the Okhotsk Sea $\left(55^{\circ} \mathrm{N}, 150^{\circ}\right.$ E)

parameters (Section 2), as we adjusted the biological parameters to focus mainly on the Northwest Pacific in the subtropical region and on subarctic regions (Ishizu et al. 2019; Eqs. 1-6). Tittensor et al. (2010) showed that biological communities in the marginal seas are dissimilar to those of the Pacific at the same latitude, suggesting that there is a limitation for the ability of the parameters optimizing method applied in the present model (Section 2.1).

\subsection{Comparison with a study based on observation data}

Yasunaka et al. (2013) discussed the inorganic carbon cycle using surface DIC climatological data, omitting physical processes such as advection and vertical mixing. Our results agree with those of Yasunaka et al. (2013) in terms of the importance of biological processes from spring to summer, especially in the subarctic region. However, in our model, biological processes are a subordinate contributor to variation in DIC compared with both vertical mixing and air-sea exchange throughout the year. The subsurface vertical structure of the biological contribution varies with latitude.

Average daily net community production (NCP) values were estimated by Yasunaka et al. (2013) from March to July as $>14 \mathrm{mmol} \mathrm{m}^{-2} \mathrm{C}$ day $^{-1}$ in the Kuroshio Extension region (140$170^{\circ} \mathrm{E}, 30-40^{\circ} \mathrm{N}$ ) and 2-6 mmol C m${ }^{-2}$ day $^{-1}$ in the subarctic region. The corresponding values of NCP in our model can be calculated as $\int_{0}^{\mathrm{MLD}} \frac{\partial[\mathrm{DIC}]}{\partial t} d z$, where MLD indicates the mixed layer depth, which is defined as the depth at which the density is $0.125 \mathrm{~kg} \mathrm{~m}^{-3}$ greater than the density at the surface (Ohishi et al. 2019; Suga et al. 2004; Ohno et al. 2004). The modeled NCP (Fig. 14) shows positive values in the subtropical region of less than $2 \mathrm{mmol} \mathrm{C} \mathrm{m}{ }^{-2}$ day $^{-1}$ and negative values in the subarctic region of less than $4 \mathrm{mmol} \mathrm{C} \mathrm{m}{ }^{-2}$ day $^{-1}$, respectively (Fig. 14), which are smaller than their respective estimated values (Yasunaka et al. 2013). In addition, our model predicts that the distinctive positive/ negative (maximum/minimum) values spread sparsely and weakly only at the boundary between the Kuroshio Extension and the subarctic region. Such differences between our model and that of Yasunaka et al. (2013) can be explained by the horizontal and vertical advection/diffusion processes represented in our model, which should be considered for better understanding of the inorganic carbon cycle in our target regions. 


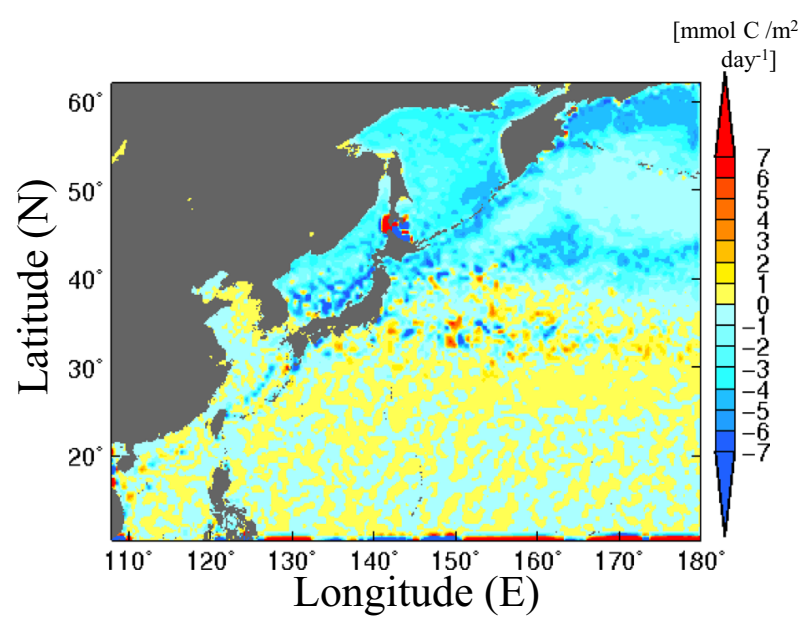

Fig. 14 Daily net community production (NCP) from March to July, estimated from our model outputs

\section{Conclusions}

To understand the seasonal inorganic carbon cycle in the Northwest Pacific, we performed simulations using a biogeochemical and carbon model coupled with an operational ocean model. The reproducibility of the model was sufficient to evaluate processes related to the seasonal inorganic carbon cycle. We found that contributions to the inorganic carbon cycle from air-sea $\mathrm{CO}_{2}$ exchange generally offset those of vertical mixing at the surface in the Northwest Pacific. Biological processes are a subordinate contributor to variation in DIC and show a latitudinal dependence in the euphotic layer. Advection actively contributes to variation in DIC below the layer where biological processes contribute.

A schematic representation of the main inorganic carbon cycle in the Northwest Pacific is shown in Fig. 15. DIC is absorbed from the atmosphere during winter south of $40^{\circ} \mathrm{N}$ and is released to the atmosphere north of $40^{\circ} \mathrm{N}$ (Fig. 15a). The DIC introduced in the subtropical region is conveyed from the surface to the subsurface by vertical mixing, and the DIC released in the subarctic region is compensated for by vertical mixing from subsurface layers (Fig. 15). In summer, the opposite pattern occurs because vertical mixing is weaker and the corresponding influence of mixing on variation in DIC decreases (Fig. 15b). Unlike the contribution from seasonal air-sea $\mathrm{CO}_{2}$ exchange, the negative contribution induced by biological processes (i.e., a sink) below the surface occurs throughout the year (Fig. 15) and becomes stronger to the subarctic region. Below the surface, the contribution of advection is prominent in the subtropical and Kuroshio Extension regions. This contribution of advection connects with the increase/decrease in DIC in the subtropical region (Fig. 15).

Ocean circulation (Tally et al. 1993; Suga and Hanawa 1995a; Yasuda et al. 1997; Qui and Chen 2006) transports DIC-rich and DIC-poor water and redistributes them over time. The horizontal pattern of long-term DIC trends varies with depth. The impacts of long-term trends in ocean acidification indices ( $\mathrm{pH}$ and aragonite saturation) also show horizontal and vertical dependencies. Future studies will use modeling experiments to evaluate decadal variations in the NPZD and carbon cycle. Results of these experiments are expected to improve our understanding of the variability in carbon, biological processes, and ocean acidification. 
(a) Winter

- phytoplankton $\sqrt{\sqrt{y}}$ degrees of vertical mixing

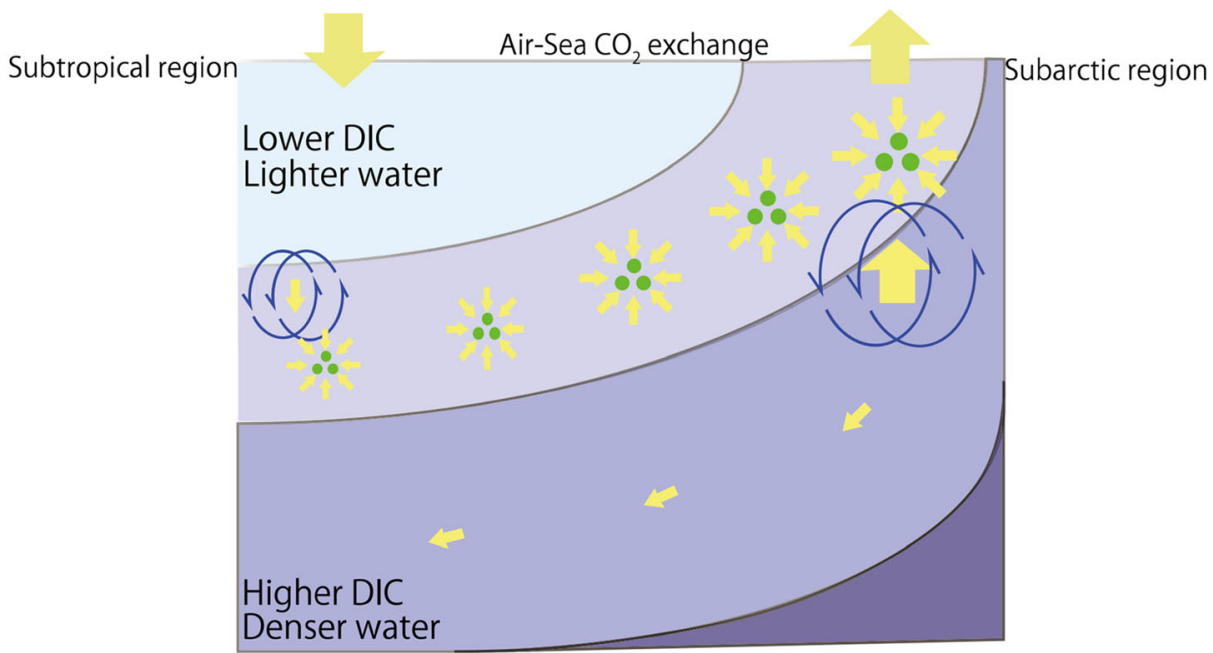

(b) Summer

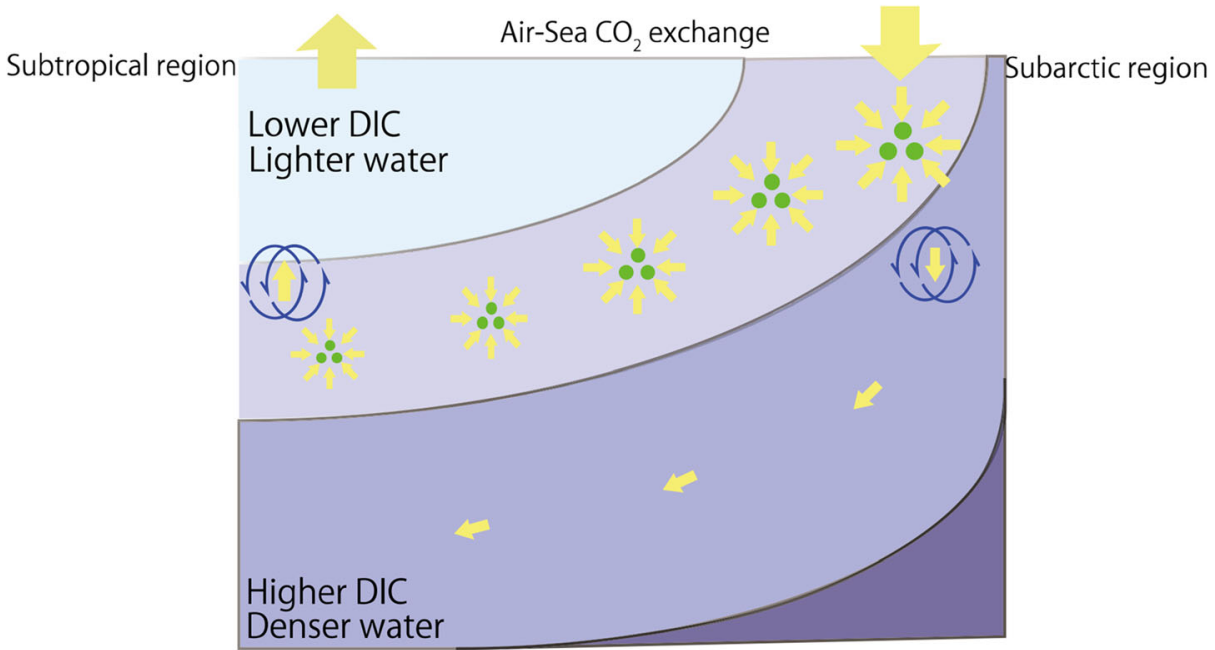

Fig. 15 Schematic views of the main inorganic carbon cycle represented in our model outputs. The figure represents the vertical distributions of the main inorganic carbon cycle with respect to longitude in the Northwest Pacific in winter (a) and summer (b). Arrows indicate the movements of inorganic carbon due to air-sea $\mathrm{CO}_{2}$ exchange, to vertical mixing, to consumption of phytoplankton, and to advection

Acknowledgments We acknowledge the continuing support from the Sasakawa Peace Foundation of the Ocean Policy Research Institute (OPRI-SPF). This study is a part of the Japan Coastal Ocean Predictability Experiment (JCOPE) sponsored by the Japan Agency for Marine-Earth Science and Technology (JAMSTEC). Comments from two anonymous reviewers helped to improve earlier versions of the manuscript. World Ocean Atlas 2001 (WOA01) and 2013 (WOA13) data were downloaded from websites of the US National Oceanographic Data Center (NODC): https://www.nodc.noaa.gov/OC5/WOA01/pr_woa01.html and https://www.nodc.noa.gov/OC5 
/woa13/, respectively. Monthly climatological data for DIN, DIP, and DIC from Yasunaka et al. (2013) were downloaded from http://soop.jp/index.html. In situ observational data from the Japan Meteorological Agency (JMA) were downloaded from https://www.data.jma.go.jp/kaiyou/db/vessel obs/data-report/html/ship/ship.php. Partial pressure data for carbon dioxide from the Ayasato observatory were downloaded from https://ds.data.jma. go.jp/ghg/kanshi/obs/co2_monthave_ryo.html. Moderate Resolution Imaging Spectroradiometer (MODIS) Aqua Ocean Color Data for 2015 were downloaded from the Physical Oceanography Distributed Active Archive Center (PODAAC) ftp site: ftp://podaac-ftp.jpl.nasa.gov/allData/modis/L3/aqua/4um/v2014.0/4km/daily/2015/.

\section{Appendix}

Figs. 16, 17, and 18, and 19

DIC variation term induced by advection effect

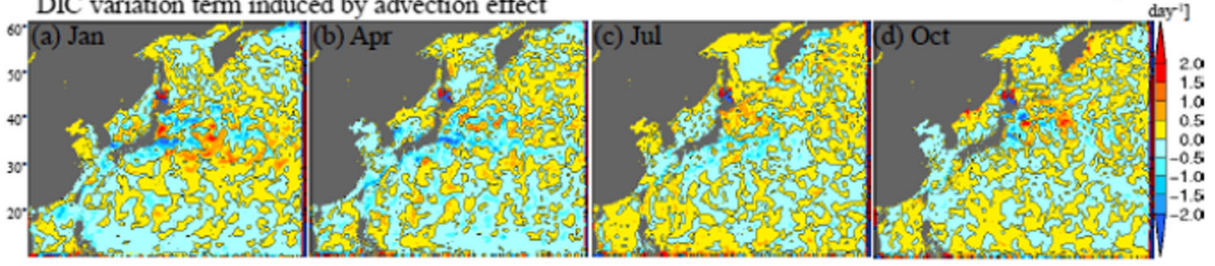

DIC variation term induced by vertical mixing

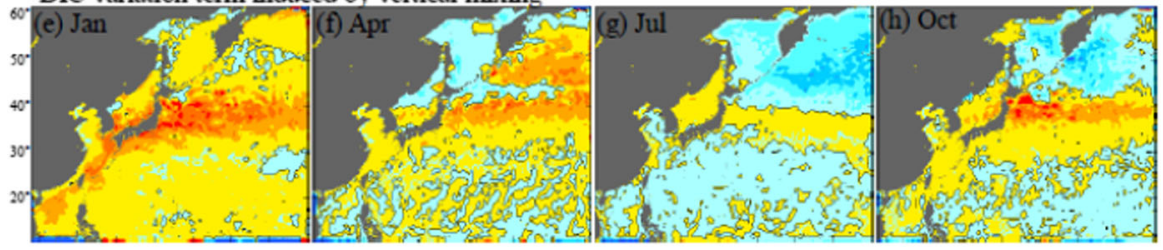

DIC variation term induced by biological processes
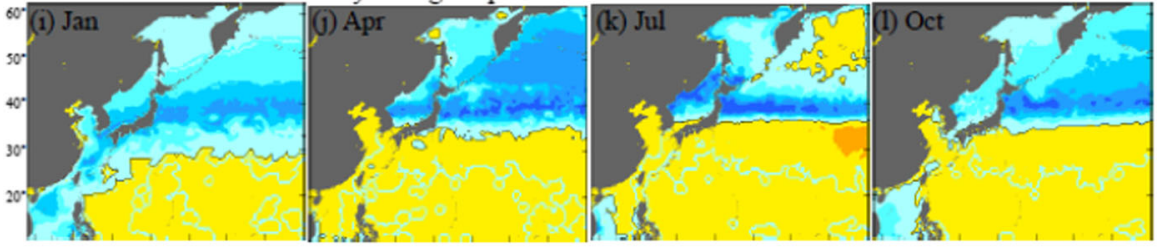

Total DIC variation term
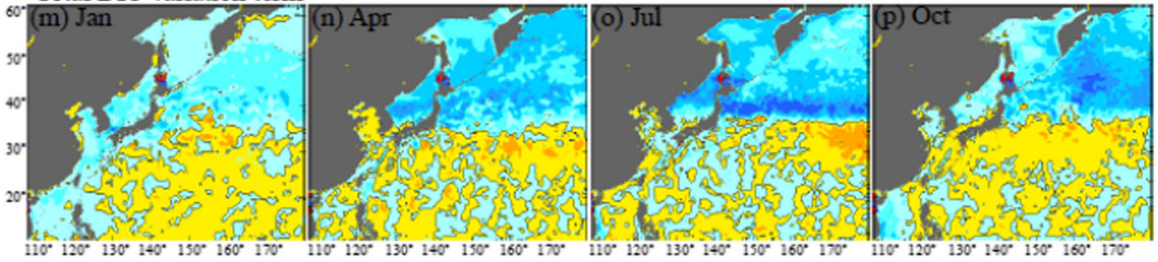

Fig. 16 Horizontal distributions of the monthly DIC variation term induced by advection (a-d), vertical mixing $(\mathrm{e}-\mathrm{h})$, biological processes (i-1), and the total DIC time variation term $(\mathrm{m}-\mathrm{p})$ at $50 \mathrm{~m}$ depth for January, April, July, and October, respectively 


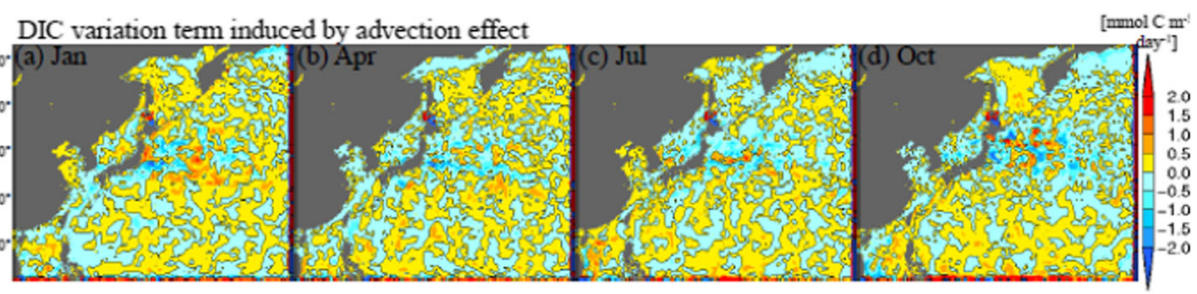

DIC variation term induced by vertical mixing

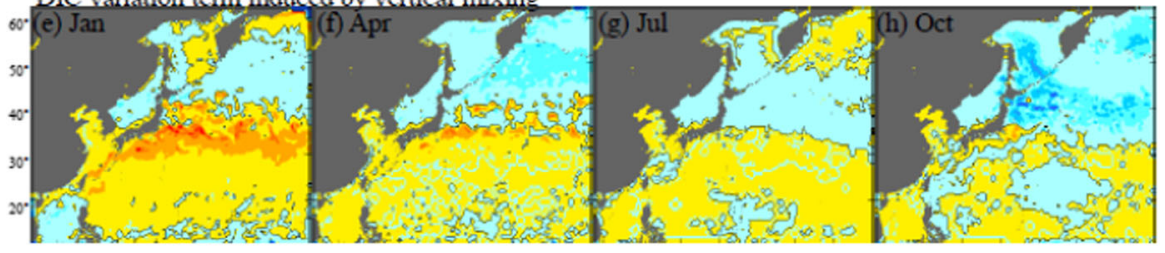

DIC variation term induced by biological processes

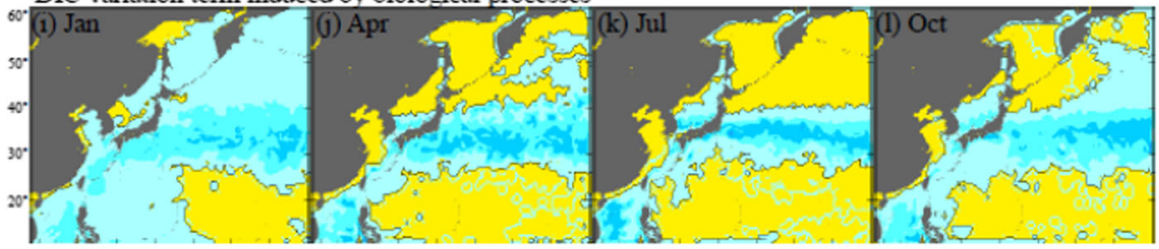

Total DIC time variation term

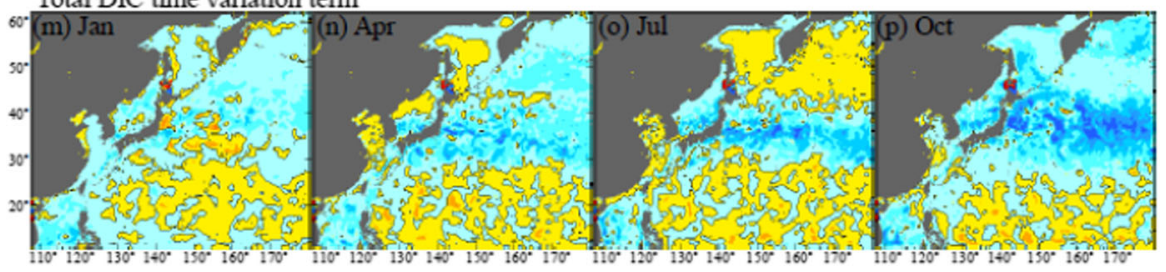

Fig. 17 Horizontal distributions of the monthly DIC variation term induced by air-sea $\mathrm{CO}_{2}$ exchange (a-d), advection $(\mathrm{e}-\mathrm{h})$, vertical mixing $(\mathrm{i}-\mathrm{l})$, biological processes $(\mathrm{m}-\mathrm{p})$, and the total DIC time variation term $(\mathrm{q}-\mathrm{t})$ at $100 \mathrm{~m}$ depth for January, April, July, and October, respectively 
DIC variation term induced by advection effect

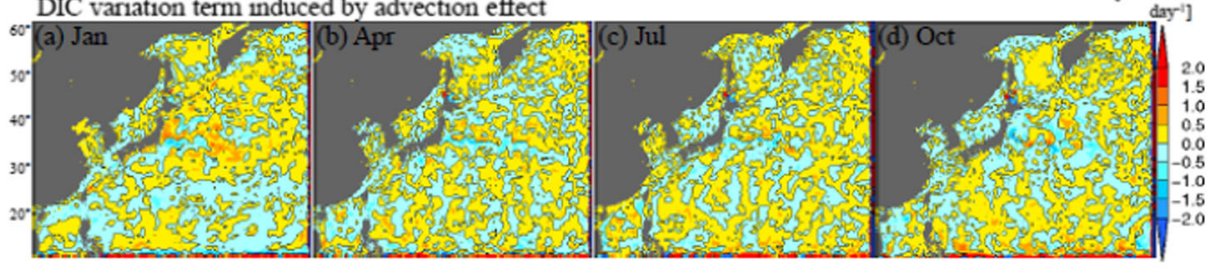

DIC variation term induced by vertical mixing

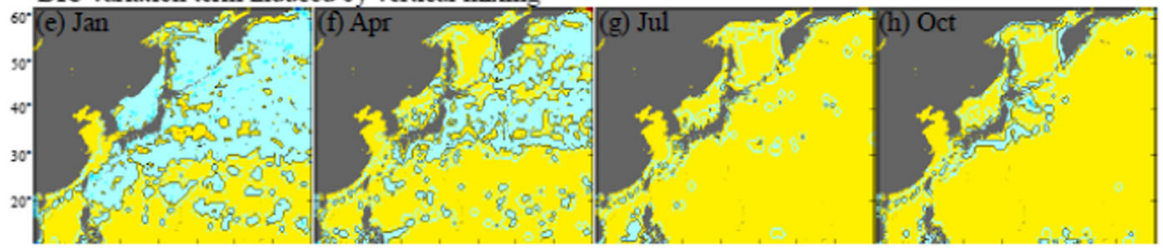

DIC variation term induced by biological processes

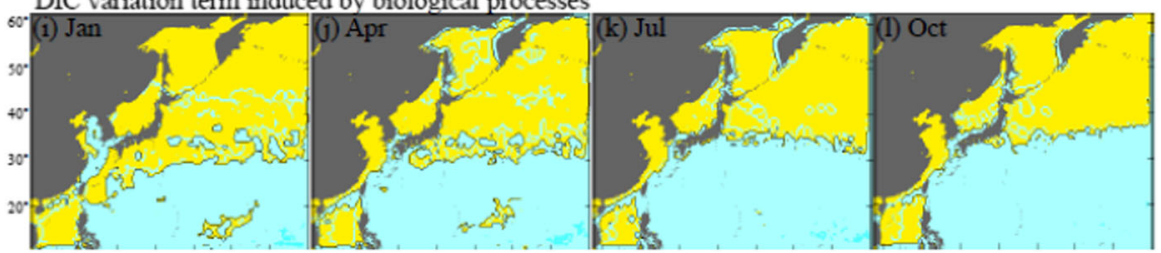

Total DIC time variation term

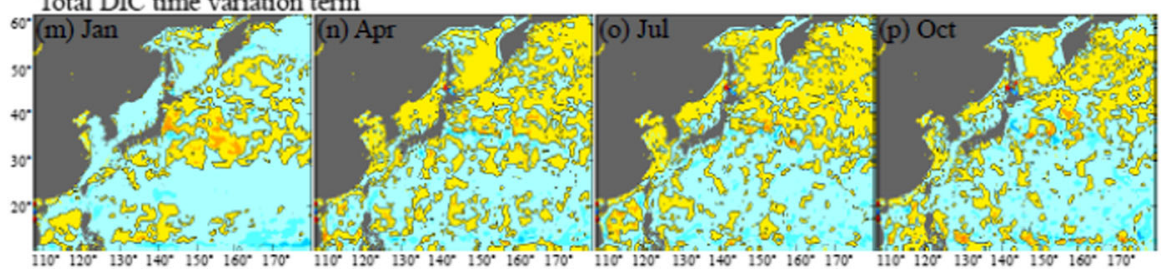

Fig. 18 Horizontal distributions of the monthly DIC variation term induced by air-sea $\mathrm{CO}_{2}$ exchange (a-d), advection $(\mathrm{e}-\mathrm{h})$, vertical mixing $(\mathrm{i}-\mathrm{l})$, biological processes $(\mathrm{m}-\mathrm{p})$, and the total DIC time variation term $(\mathrm{q}-\mathrm{t})$ at $200 \mathrm{~m}$ depth for January, April, July, and October, respectively 
We calculated air-sea $\mathrm{CO}_{2}$ fluxes (Fig. 8(a-d)) as $\rho_{w} V_{p} k_{0 C}\left(P_{\mathrm{CO}_{2}}-P_{\mathrm{CO}_{2}}^{\mathrm{atm}}\right)$ (Kantha, 2004; Ishizu et al. 2019), where $\rho_{\mathrm{w}}$ is the density of seawater $\left(\mathrm{kg} \mathrm{m}^{-3}\right) ; k_{0 C}$ is the solubility of $\mathrm{CO}_{2}$ in seawater (mol kg-1 $\mathrm{atm}^{-1}$; Weiss 1974); $V_{\mathrm{p}}$ is the piston velocity, which depends on wind speed $\left(U_{10}\right)$ and the Schmidt number $\left(S_{c}\right)$ and is expressed in units of $\mathrm{m} \mathrm{s}^{-1}$ $\left(V_{\mathrm{p}}=8.61 \times 10^{-7} U_{10}^{2}\left(S_{c} / 660\right)^{-1 / 2}\right.$; Wanninkhof, 1992); and $P_{\mathrm{CO}_{2}}$ and $P_{\mathrm{CO}_{2}}^{\mathrm{atm}}$ are the partial pressures of $\mathrm{CO}_{2}$ in surface waters and the atmosphere ( $\left.\mu \mathrm{atm}\right)$, respectively.

Compared with the global air-sea $\mathrm{CO}_{2}$ fluxes evaluated on the basis of monthly climatological data (Takahashi et al. 2002, 2009; Yasunaka et al. 2013), our model provides a finer spatiotemporal resolution of variability, with both strong and weak contrasts in air-sea $\mathrm{CO}_{2}$ fluxes in the target region (not shown). The seasonal changes in air-sea $\mathrm{CO}_{2}$ flux simulated by our model (Fig. 8(a-d); note that the values in Fig. 8(a-d) do not represent the actual air-sea $\mathrm{CO}_{2}$ flux, but the contribution of air-sea $\mathrm{CO}_{2}$ exchange to the total DIC balance) are similar to the seasonal climatology (Takahashi et al. 2002; Yasunaka et al. 2013), although the annual mean air-sea $\mathrm{CO}_{2}$ flux (Fig. 19) indicates a smaller sink in the Kuroshio Extension region between $30^{\circ} \mathrm{N}$ and $40^{\circ} \mathrm{N}$, and the transition between sink and source areas is less distinct than that in the climatology (Takahashi et al. 2002; Yasunaka et al. 2013). For example, the climatology (Yasunaka et al. 2013) shows an extensive sink area between $30^{\circ} \mathrm{N}$ and $40^{\circ} \mathrm{N}$ of $>6 \mathrm{mmol} \mathrm{m}^{-2} \mathrm{C}$ day $^{-1}$, but our model predicts a mixture of sink and source areas in the range from -5 to $5 \mathrm{mmol} \mathrm{m}^{-2} \mathrm{C}_{\text {day }^{-1}}$. One reason for the relatively weak sink areas predicted by our model may be uncertainty in the calculation of $\mathrm{pCO}_{2}$, as revealed by the MATLAB program $\mathrm{CO}_{2}$ sys.m (Orr and Epitalon 2015; Mackenzie et al. 2004). The calculation of $\mathrm{pCO}_{2}$ performed here gives higher $\mathrm{pCO}_{2}$ values in the ocean compared with the $\mathrm{pCO}_{2}$ climatology (Nakaoka et al. 2013). While et al. (2012) also referred to large estimation in the calculation of $\mathrm{pCO}_{2}$.
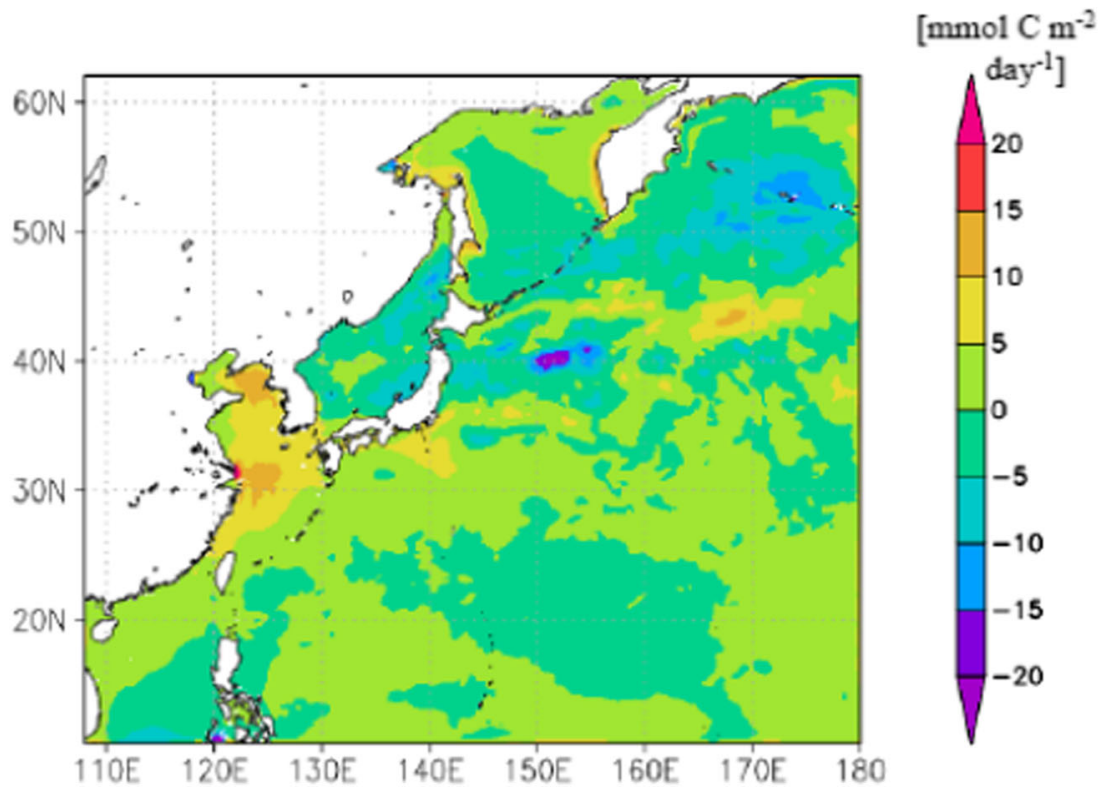

Fig. 19 Annual mean air-sea $\mathrm{CO}_{2}$ flux in 2015 
Open Access This article is licensed under a Creative Commons Attribution 4.0 International License, which permits use, sharing, adaptation, distribution and reproduction in any medium or format, as long as you give appropriate credit to the original author(s) and the source, provide a link to the Creative Commons licence, and indicate if changes were made. The images or other third party material in this article are included in the article's Creative Commons licence, unless indicated otherwise in a credit line to the material. If material is not included in the article's Creative Commons licence and your intended use is not permitted by statutory regulation or exceeds the permitted use, you will need to obtain permission directly from the copyright holder. To view a copy of this licence, visit http://creativecommons.org/licenses/by/4.0/.

\section{References}

Bauer JF, Cai WJ, Raymond PA, Bianchi TS, Hopkinson CH, Pierre A, Regnier P (2013) The changing carbon cycle of the coastal ocean. Nature 504:61-70. https://doi.org/10.1038/nature12857

Cai W-J, Dai HM, Wang CY (2006) Air-sea exchange of carbon dioxide in ocean margins: a province-based synthesis. Geophysical Res Letter 33:L12603. https://doi.org/10.1186/1472-6785-8-15

Goyet C, Healy R, Ryan J (2000) Global distribution of total inorganic carbon and total alkalinity below the deepest winter mixed layer depths, ORNL/CDIAC-127, NDP-076. In: Carbon Dioxide Information Analysis Center, Oak Ridge National Laboratory. U.S. Department of Energy, Oak Ridge, TN, USA, pp 1-40. https://doi.org/10.3334/CDIAC/otg.ndp076

IGBP, IOC, SCOR (2013) Ocean acidification summary for policymakers - third symposium on the Ocean in a High- $\mathrm{CO}_{2}$ World International Geosphere-Bioshere Programme. Stockholm, Sweden

IPCC, Summery for Policymakers. In: Climate Change 2013: The physical science basis. Contribution of working group I to the fifth assessment report of the Intergovernmental Panel on Climate Change [Stocker, T.F., D. Qin, G.-K. Plattner, M. Tignor, S.K. Allen, J.Boschung, A. Nauels, Y. Xia, V. Bex and P.M. Midgley (eds.)]. Cambridge University press, United Kingdom and New York, NY, USA. 2013, pp.129

Ishizu M, Miyazawa Y, Tsunoda T, Guo X (2019) Development of a biogeochemical and carbon model related to ocean acidification indices with an operational ocean model product in the northwestern Pacific. Sustainability 11:2677. https://doi.org/10.3390/su11092677

Keller, M. K.; Joos, F.; Raible, C. C.: Time of emergence of trends in ocean biogeochemistry, Biogeosciences, 11,3647-3659, 2014, www.biogeosciences.net/11/36472014/, doi.https://doi.org/10.5194/bg-11-3647-2014

Key MR, Kozyer A, Sabine LC, Lee K, Wanninkhof R, Bullister LJ, Feely AR, Millero JF, Mordy C, Peng TH (2004) A global ocean carbon climatology: results from global data analysis project (GLODAP). Glob Biogeochem Cycles 18:GB4031. https://doi.org/10.1029/2004GB002247

Laruelle GG, Durr HH, Slomp PC, Borges VA (2010) Evaluation of sinks and sources of CO2 in the global coastal ocean using a spatiallyexplicit typology of estuaries and continental shelves. Geophys Res Lett 37: L15607. https://doi.org/10.1029/2010GL043691

Li PQ, Franks JSP, Landry RM, Goericke R, Taylor GA (2010) Modeling phytoplankton growth rates and chlorophyll to carbon ratios in California coastal and pelagic ecosystems. J Geophys Res 115:G04003. https://doi.org/10.1029/2009JG001111

Lovenduski NS, Long CM, Lindsay K (2015) Natural variability in the surface ocean carbonate ion concentration. Biogeosciences 12:6321-6335. https://doi.org/10.5194/bg-12-6321-2015

Luo X, Wei H, Liu Z, Zhao L (2015) Seasonal variability of air-sea $\mathrm{CO}_{2}$ fluxes in the yellow and East China seas: a case study of continental shelf sea carbon cycle model. Cont Shelf Res 107:69-78

Mackenzie FT, Lerman A, Anderson AJ (2004) Past and present of sediment and carbon biogeochemical cycling models. Biogeosciences 1:11-32

Mellor GL (2001) An equation of state for numerical models of oceans and estuaries. Journal of Atmospheric and Oceanic technology 199(8):609-611

Miyazawa Y, Zhang R, Guo X, Tamura H, Ambe D, Lee JS, Yoshinari H, Setou T (2009) Water mass variability in the western North Pacific detected in a 15-year eddy resolving ocean reanalysis. J Oceanogr 65:737-756

Miyazawa Y, Yamashita N, Taniyasu S, Yamazaki E, Guo X, Varlamov MS, Miyama T (2014) Ocean dispersion simulation of perfluoroalkyl substances in the Western North Pacific associated with the great East Japan earthquake of 2011. J Oceanogr 70:535-547

Miyazawa Y, Varlamov MS, Miyama T, Guo X, Hihara T, Kiyomatsu K, Kachi M, Kurihara Y, Murakami H (2017) Assimilation of high-resolution sea surface temperature data into an operational nowcast/forecast system around Japan using a multi-scale three-dimensional variational scheme. Ocean Dyn 67:713-728 
Nakaoka S, Telszewski M, Nojiri Y, Yasunaka S, Miyazaki C, Mukai M, Usui N (2013) Estimation temporal and spatial variation of ocean surface pCO2 in the North Pacific using a self-organizing map neural network technique. Biogeosciences 10:6093-6106. https://doi.org/10.5194/bg-10-6093-2013

Ohishi S, Aiki H, Tozuka T, Cronin FM (2019) Frontolysis by surface heat flux in the eastern Japan Sea: importance of mixed layer depth. J Oceanogr 75:283-297

Ohno Y, Kobayashi T, Iwasaka N, Suga T (2004) The mixed layer depth in the North Pacific as detected by Argo floats. Geophysical Research Letter 63:125-134

Oka E, Qui B (2012) Progress of North Pacific mode water research in the past decade. J Oceanogr 68:5-20. https://doi.org/10.1007/s10872-011-0032-5

Oka E, Suga T (2005) Differential formation and circulation of North Pacific central mode water. J Phys Oceanogr 35:1997-2011

Orr CJ, Epitalon MJ (2015) Improved routines to model the ocean carbonate system: mocsy 2.0. Geosci. Model Dev. 8:485-499. https://doi.org/10.5194/gmd-8-485-2015

Palmer JR, Totterdell IJ (2001) Production and export in a global ocean ecosystem model. Deep-Sea Research I 48:1169-1198

Qui B, Chen S (2006) Decadal variability in the formation of the North Pacific subtropical mode water; oceanic versus atmospheric control. Joural of Physical Oceanography 36:1365-1380

Sauzede, R.; Lavigne, H.; Claustre, H.; Schmechtig, C.; Ortenzio, D. F.; Guinet, C.; Pesant, S. Vertical distribution of chlorophyll-a concentration and phytoplankton community composition from in situ flurorescence profiles: a first database for the global ocean. Earth Syst Sci Data, 7, 2015, 261-273., doi: 10.5194/essd-7-261-2015

Stelmakh L, Gorbunova IT (2018) Carbon-to-chlorophyll-a ratio in the phytoplankton of the Black Sea surface layer: variability and regulatory factors. Ecologica Montenegria 17:60-73

Suga T, Motoki K, Aoki Y, MacDonald A (2004) The North Pacific climatology of winter mixed layer and mode waters. J Phys Oceanogr 34:3-22

Sutton, J. A.; Wanninkhof, R.; Sabine, L. C., Feely, A. R.; Cronin, F. M; Weller, A. R.; Variability and trends in surface seawater $\mathrm{pCO}_{2}$ and $\mathrm{CO}_{2}$ flux in the Pacific Ocean. Geophysical Research Letter, 2017, 44, 56275636, doi:https://doi.org/10.1002/2017GL073814

Takahashi T, Sutherland CS, Sweeney C, Poisson A, Metzl N, Tilbrook B, Bates N, Wanninkhof R, Feely AR, Sabin C, Olafsson J, Nojiri Y (2002) Global Sea-air $\mathrm{CO}_{2}$ flux based on climatological surface ocean $\mathrm{pCO}_{2}$, and seasonal biological and temperature effects. Deep-Sea Research II 49:1601-1622

Takahashi T, Sutherland CS, Wanninkhof R, Sweeney C, Feely AR, Chipman WD, Hales B, Friedrich G, Chaves F, Sbaine C, Watson A, Bakker CED, Schuster U, Metzl N, Yoshika-Wainoue H, Ishii M, Midorikawa T, Nojiri Y, Kortzinger A, Steinhoff T, Hoppema M, Olafsson J, Arnarson ST, Tilbrook B, Johannessen T, Olsen A, Bellerby R, Wong CS, Delille B, Bates NR, de Baar JWH (2009) Climatological mean and decadal change in surface ocean $\mathrm{pCO}_{2}$ and net sea-air $\mathrm{CO}_{2}$ flux over the global oceans. Deep-Sea Research II 56:554-577

Takahashi T, Sutherland CS, Chipman WD, Goddard GJ, Cheng H, Newberger T, Sweeney C, Munro RD (2014) Climatological distributions of $\mathrm{pH}, \mathrm{pCO}_{2}$, total $\mathrm{CO}_{2}$, alkalinity, and $\mathrm{CaCO}_{3}$ saturation in the global surface ocean, and temporal changes at selected locations. Mar Chem 164:95-125

Takatani Y, Enyo K, Iida, Kojima A, Sasano D, Kosugi N, Midorikawa, Suzuki T, Ishii M (2014) Relationships between total alkalinity in surface water and seas surface dynamic height in the Pacific Ocean. Journal of Geophysical Research Oceans 119:2806-2814. https://doi.org/10.1002/2013JC009739

Tittensor D, Mora C, Jetz W, Lotze H, Ricard D, Vanden Berghe E, Worm B (2010) Global patterns and predictors of marine biodiversity across taxa. Nature 466(7310):1098-1101. https://doi.org/10.1038 /nature09329

Tsuda, A.; Takeda, S.; Saito, H.; Nishioka, J.; Nojiri, Y.; Kudo, I.; Kiyosawa, H.; Imai, K.; Ono, T.; Shimamoto, A.; Tsumune, D.; Yoshimura, T.; Aono, T.; Hinuma, A.; Kinugasa, M.; Suzuki, K.; T. A mesoscale iron enrichment in the western subarctic Pacific induces large centric diatom bloom. Science, 2003, 958-961. doi: https://doi.org/10.1126/science. 1082000

Wanninkhof R, Park HG, Takahashi T, Sweeney C, Feely R, Nojiri Y, Gruber N, Doney CS, McKinely AG, Lenton A, Le Quere C, Heinze C, Schwinger J, Garven H, Khatiwala S (2013) Global Ocean carbon uptake: magnitude, variability and trends. Biogeosciences 10:1983-2000. https://doi.org/10.5194/bg-10.1983-2013

Weiss R (1974) The provisions of social relationships. In: Rubin Z (ed) Doing unto others. Prentice Hall, Englewood Cliffs, pp 17-26

While J, Totterdell I, Martin M (2012) Assimilation of $\mathrm{pCO}_{2}$ data into a global coupled physical-biogeochemical ocean model. Journal of Geophysical Research 117:C03037. https://doi.org/10.1029/2010JC006815

Xiu P, Chai F (2013) Variability of oceanic carbon cycle in the North Pacific from seasonal to decadal scales. J. Geophys. Res Oceans 119:5270-5288. https://doi.org/10.1002/2013JC009505 
Yasunaka S, Nojiri Y, Nakaoka S, Ono T, Mukai H, Usui N (2013) Monthly maps of sea surface dissolved inorganic carbon in the North Pacific: basin-wide distribution and seasonal variation. J Geophys Res Oceans 118:3843-3850. https://doi.org/10.1002/jgrc.20279,2013

Yasunaka S, Nojiri Y, Nakaoka S, Ono T, Whitney F, Telszewski M (2014) Mapping of sea surface nutrients in the North Pacific: basinwide distribution and seasonal to interannual variability. J. Geophys. Res. Oceans 119:7756-7771. https://doi.org/10.1002/2014JC010318

Publisher's note Springer Nature remains neutral with regard to jurisdictional claims in published maps and institutional affiliations. 